\title{
THE TRIUMPH OF THE SOUTHERN MAN: DOWELL, SHELBY COUNTY, AND THE JURISPRUDENCE OF JUSTICE LEWIS F. POWELL, JR.
}

\author{
EARL M. MALTZ*
}

\begin{abstract}
The year 2018 has witnessed widespread celebrations of the life and legacy of Dr. Martin Luther King, Jr., who was assassinated fifty years ago in Memphis, Tennessee. Yet if Dr. King were alive today, he would no doubt be dismayed by the path taken by the Supreme Court's treatment of race-related issues in recent years. Not only has the Court abandoned the quest for school desegregation, but the 2013 decision in Shelby County v. Holder substantially reduced the effectiveness of the Voting Rights Act of 1965, which was the most important legislative monument to Dr. King's efforts.

By contrast, these developments would no doubt have pleased Lewis F. Powell, Jr., a harsh critic of Dr. King who joined the Supreme Court less than four years after King's death. Prior to taking his seat on the Court, Powell had been openly critical of the decision in Brown v. Board of Education, and in his capacity as chair of the school board of Richmond, Virginia, had worked ceaselessly to limit the pace and scope of the desegregation of the Richmond schools. Moreover, even before joining the Court, he had actively sought to limit the impact of the Voting Rights Act on the decision-making authority of state and local governments in the South. Similarly, in the cases that came before him after coming to the Court, Powell consistently voted to limit the scope of remedial orders in desegregation cases and argued that the Constitution imposed important limits on the scope of congressional authority to deal with the issues that the Voting Rights Act was designed to address.
\end{abstract}

Copyright (C) 2019 Earl M. Maltz.

*Distinguished Professor, Rutgers University School of Law. 
Powell had only limited success in persuading a majority of his colleagues to support him on these issues. However, the reasoning of the Court's decisions in the years after Powell left the Court in 1987 has often embraced the arguments made by Powell during his tenure as a justice. This article not only explores Powell's background and jurisprudence, but also provides the first scholarly discussion of the relationship between his views and the positions currently taken by the Court.

\section{TABLE OF CONTENTS}

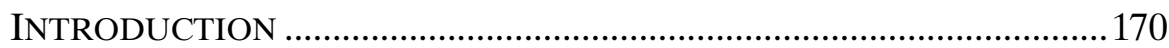

I. THE MAKING OF A SOUTHERN GENTLEMAN .................................172

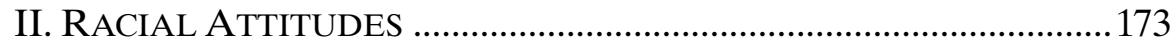

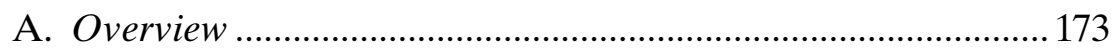

B. Powell and the Aftermath of Brown .......................................... 176

C. The Ongoing Struggle Over the Desegregation of the Richmond

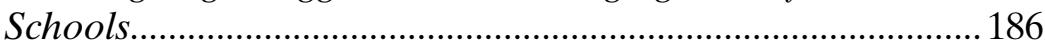

D. Powell and the Prince Edward County Schools ........................ 188

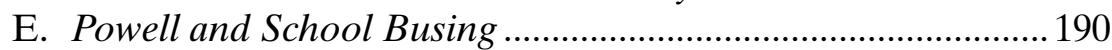

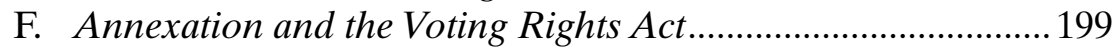

III. POWELL ON THE SUPREME COURT ..................................................208

A. Nomination and Confirmation..................................................208

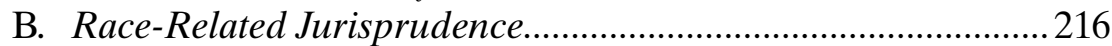

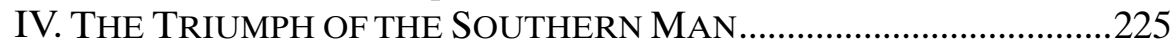

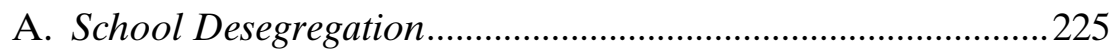

B. The Death of the Preclearance Requirement ............................229

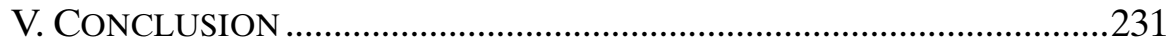

\section{INTRODUCTION}

The Supreme Court's attitude toward issues involving school desegregation and voting rights has changed significantly in recent years. During the period between the mid-1960s and the early 1990s, a majority of the justices embraced two principles in dealing with such issues. First, although not as aggressive as many progressives would have preferred, the Court itself was actively involved in promoting racial balance in public schools in both the North and the South. ${ }^{1}$

1. See, e.g., Columbus Bd. Of Educ. v. Penick, 443 U.S. 449 (1979); Swann v. Charlotte- 
Second, the justices were willing to countenance even more aggressive actions by the federal government that were designed to ensure that African-Americans in particular were treated fairly by state governments. $^{2}$

One of the early signs of a change in the Court's approach to these issues came with the 1991 decision in Board of Education of Oklahoma City v. Dowell, ${ }^{3}$ where the justices signaled their retreat from involvement in the process of school desegregation. More than two decades later, in Shelby County v. Holder ${ }^{4}$ the Court took even more dramatic action, effectively invalidating the preclearance provision of the Voting Rights Act of 1965, which had been designed to ensure that changes in state voting and election laws would not undermine the ability of African-Americans to participate fully in electoral politics. In both cases, the Court took the position that the conditions that once justified such aggressive measures had largely disappeared.

While both Dowell and Shelby County have been the subject of extensive academic commentary, scholars have not focused on the relationship between the perspective on race relations that underlay those decisions and that which informed the jurisprudence of Justice Lewis F. Powell, Jr., who served on the Court from 1972 through 1987. Powell was a pillar of the white establishment in Richmond, Virginia, and was the chair of the city school board during the period immediately following the decision in Brown v. Board of Education. ${ }^{5}$ Although he opposed the doctrine of massive resistance, Powell was openly critical of the Brown decision and consistently sought to limit the impact of the decision on the racial composition of the Richmond schools. In addition, he objected to the use of the preclearance requirement of the Voting Rights Act to prevent the implementation of a measure that was clearly designed to perpetuate white control of the Richmond City Council.

By the time that Powell joined the Court, he had apparently become reconciled to the basic principles embodied in Brown. Nonetheless, he continued to oppose both the use of aggressive

Mecklenburg Bd. of Educ., 402 U.S. 1 (1971).

2. See, e.g., City of Rome v. United States, 446 U.S. 156 (1980); S.C. v. Katzenbach, 383 U.S. 301 (1966).

3. 498 U.S. 237 (1991).

4. 570 U.S. 529 (2013).

5. 347 U.S. 483 (1954). 
measures designed to improve the racial balance of previously segregated schools and the imposition of the preclearance requirement on the South. More generally, Powell's treatment of the race-related issues that came before the Court during his tenure as a justice emphasized his conviction that systemic racial discrimination was largely a thing of the past, and that any lingering vestiges of racism could generally be addressed adequately without disrupting the existing structure of governmental institutions. Powell was unable to convince a majority of his colleagues on the Burger Court to follow his lead in cases dealing with school desegregation and voting rights. By contrast, as this article demonstrates, the arguments that Powell made in those cases were the precursors of the analysis that would later underlie the positions taken by the Court in cases such as Dowell and Shelby County.

\section{THE MAKING OF A SOUTHERN GENTLEMAN ${ }^{6}$}

Lewis Franklin Powell, Jr. was born in Suffolk, Virginia on September 19, 1907. After spending several years in the Richmond public school system, Powell attended McGuire's University School, a private, college preparatory high school which generally sought to send its graduates to the University of Virginia. However, hoping for an opportunity to play intercollegiate baseball, Powell chose instead to attend Washington and Lee College, a segregated, all-male institution that was deeply steeped in the traditions of the Old South.

Although Powell was unable to earn a place on the college baseball team, he achieved great success in a wide variety of other endeavors while at Washington and Lee. In addition to graduating magna cum laude with a degree in business and being elected to Phi Beta Kappa, he became the president of both his fraternity and the student body as a whole, was managing editor of the school newspaper, worked on the staff of the yearbook, and helped produce campus balls. In recognition of his accomplishments, Powell received the Algernon Sidney Sullivan Medallion, which was awarded to the student "who excels in high ideals of living, in spiritual qualities, and in genuine and disinterested service to others." "

6. The description of Powell's early life and education is taken from JOHN C. JEFFRIES, JR., JUSTICE LEWIS F. POWELL, JR. (1994).

7. Id. at $26-31$. 
From the time that he entered college, believing that "soldiers and lawyers made most of the history," 8 Powell's goal was to attend law school. By beginning to take law courses as an undergraduate, Powell was able to finish both his undergraduate and law school courses at Washington and Lee in six years, graduating first in his law school class in June, 1931. At the insistence of his father, Powell then spent a post-graduate year at Harvard Law School, receiving an LL.M. degree in $1932 .{ }^{9}$

Following his year at Harvard, Powell was offered a position as an associate at the Wall Street law firm of Davis Polk and Wardwell. However, he chose instead to return to Richmond. After practicing for three years with a small firm, Powell accepted a position as an associate at Hunton, Williams, Anderson, Gay and Moore, [hereinafter Hunton, Williams] the preeminent law firm in the city, ${ }^{10}$ and remained with that firm until he joined the Supreme Court in 1972.

In addition to his private practice, Powell immersed himself in the civic life of the city of Richmond and the state of Virginia. Believing that pro bono work was "a duty of citizenship that should be undertaken quite apart from the possibility of establishing broader personal recognition" and also had the "positive by-product" of enhancing the standing of a young lawyer in the community, ${ }^{11}$ Powell became well known for providing free legal services to a wide variety of charitable organizations. In addition, Powell took a strong interest in political and governmental affairs. In 1947, he was elected to the commission that rewrote the city charter. Three years later, Powell was chosen to serve on the Richmond School Board. In 1961, he was appointed to the state Board of Education and in 1968 became a member of the Commission on Constitutional Revision that was charged with the task of revising the state constitution. ${ }^{12}$

\section{RACIAL ATTITUDES}

\section{A. Overview}

Powell came of age at a time when Virginia society, like that of the other states in the South, was rigidly segregated by race. The policy of

8. Id. at 30 .

9. Id. at 37-39.

10. Id. at 44-46.

11. Id. at 123-24.

12. Id. 
segregation was embodied in the Jim Crow laws that required the separation of whites and African-Americans on railroads and in public schools and places of amusement. Moreover, during the early twentieth century, political power in the Southern states rested entirely with the white population. Although formally prohibited by the Fifteenth Amendment from using race as a qualification for voting, Virginia and the other Southern states used a wide variety of formal and informal measures to prevent or discourage AfricanAmericans from participating in the political process. As a result, in 1940, fewer than five percent of the voting age African-Americans in the South were registered to vote. ${ }^{13}$

The maintenance of racial segregation met little resistance from federal authorities in the early twentieth century. However, beginning in the 1940s, segregation came under increasing attack from several different quarters. During that period, the Supreme Court became more receptive to constitutional attacks on racial classifications. ${ }^{14}$ Even more importantly, the opponents of the Jim Crow system began to gain traction within the political branches of the federal government.

A speech made by President Harry S. Truman on February 2, 1948, reflected the growing opposition to the practice of racial segregation that pervaded Southern society. The speech was a response to a report that had been issued by a Committee on Civil Rights which had been created by Truman on December 5, 1946. The Committee's mandate was to "make recommendations with respect to the adoption or establishment, by legislation or otherwise, of more adequate and effective means and procedures for the protection of the civil rights of the people of the United States." In his speech, Truman called for, among other things: the establishment of a permanent Commission on Civil Rights, a Joint Congressional Committee on Civil Rights, and a Civil Rights Division in the Department of Justice; the strengthening of existing civil rights statutes; the passage of statutes specifically aimed at providing federal protection against lynching and protecting the right to vote from discriminatory action by public officials based on race, color or "other unreasonable classification"; the establishment of a Fair Employment Practice Commission to prevent

13. Kraig Beyerlein and Kenneth T. Andrews, Black Voting During the Civil Rights Movement: A Micro-Level Analysis, 87 SOCIAL FORCES 1, 4 (2008).

14. See, e.g., Shelley v. Kraemer, 334 U.S. 1 (1948) (prohibiting enforcement of raciallyrestrictive covenants); Smith v. Allwright, 321 U.S. 649 (1944) (outlawing white primaries). 
unfair discrimination in employment; and a prohibition on racial discrimination in interstate transportation facilities. ${ }^{15}$ Five months later, sounding a similar note, the Democratic National Convention adopted a platform that praised Truman for his stand on civil rights and called for passage of federal legislation that would guarantee "(1) the right of full and equal political participation; (2) the right to equal opportunity of employment; (3) the right of security of person; (4) and the right of equal treatment in the service and defense of our nation." 16

Truman's speech was condemned by the representatives of the Southern white establishment in the strongest possible terms. For example, Senator Harry F. Byrd, the patriarch of the political system in the state of Virginia, analogized the proposed statute on voting rights to actions taken by Adolf Hitler and Joseph Stalin and declared that, taken together, Truman's proposals comprised "a mass invasion of states' rights never before even suggested, much less recommended, by any previous President of any party affiliation in the nation's history" and "could very conceivably lead to dictatorship." 17

Powell took a similar view of Truman's civil rights initiatives. While insisting that he had never been a racist and that he had always had personal friends in the African-American community, Powell later conceded that, as late as 1954, he had no difficulty in accepting the idea that racial segregation should be mandated by law. ${ }^{18}$ Thus, in 1952, Powell worried that, if elected, Democratic presidential candidate Adlai Stevenson "will be more successful than Truman in obtaining the passage of pet left wing legislation such as [a bill establishing the Fair Employment Practices Commission]" and that such legislation would accelerate "the trend toward socialism." 19 Although Stevenson was defeated, Powell would soon be faced with the problem of dealing with the Supreme Court's 1954 decision in

15. Special Message to the Congress on Civil Rights, Feb 2, 1948, HARRY S. TrUMAN PRESIDENTIAL LIBRARY \& MUSEUM, https://www.trumanlibrary.org/publicpapers/index.php? pid=1380\&st $=\&$ st1 $=($ last visited Mar. 31, 2019).

16. 1948 Democratic Party Platform, AMERICAN PresidenCy ProJect, http://www.presidency.ucsb.edu/ws/index.php?pid=29599 (last visited Mar. 31, 2019).

17. BYRD SAYS 'RIGHTS' MEANS DICTATORSHIP: Truman Board Seeks Power of Kind Hitler and Stalin Got, He Tells Richmond Rally, N.Y. TIMES, Feb 20, 1948, at 3.

18. JEFFRIES, supra note 6, at 139.

19. A. C. Pritchard, Justice Lewis F. Powell, Jr. and the Counterrevolution in Federal Securities Law, 52 DUKE L.J. 841, 855 n.88 (2003) (quoting Justice Powell). 
Brown v Board of Education, ${ }^{20}$ which posed a direct challenge to the maintenance of the Jim Crow system.

\section{B. Powell and the Aftermath of Brown}

As the chair of the Richmond school board, Powell was forced to directly confront the implications of Brown. After the decision was announced, Powell stated privately that "I am not in favor of, and will never favor compulsory integration." ${ }^{21}$ However, unlike many white Southerners, Powell did not believe that Southern whites should openly defy the mandates of the Supreme Court. Instead, like other, more moderate opponents of school desegregation, he took the view that the governments of the Southern states should take measures that were formally consistent with the requirements imposed by Brown but that nonetheless left the schools almost entirely segregated in fact. ${ }^{22}$

Initially, it seemed that this view might also shape the official policy of the state of Virginia. On November 11, 1955, a committee chaired by state senator Garland Gray, and charged by Virginia Governor Thomas B. Stanley with the task of making recommendations on how best to respond to Brown proposed a number of measures designed to provide for the continued existence of a system of public education in the state, while at the same time "making provision for localities wherein public schools are abandoned, and providing educational opportunities for children whose parents will not send them to integrated schools." The proposed legislation would have given local school boards broad discretion to determine the public schools to which individual students would be assigned, subject to the proviso that no student would be reassigned from the school that he was currently attending absent "good cause shown." In making assignments under the Gray Commission Plan, the local boards would have been authorized to consider not only the welfare of the child being assigned, but also "the welfare and best interests of all other pupils attending a particular

20. 347 U.S. 483 (1954).

21. JEFFRIES, supra note 6, at 140.

22. See generally ANDERS WALKeR, THE GHOST OF Jim CROW: HOW SOUTHERN Moderates Used BROWN V. BOARD OF EDUCATION to Stall Civil Rights (2009) (describing the ideology of white Southern moderates and the tactics that they employed in detail). 
school," as well as other factors such as the availability of facilities and transportation, and the "health [and] aptitude of the child."23

In addition to proposing that local school boards be allowed great discretion in assigning students to schools, the Gray Commission report also made a number of other specific proposals that were clearly intended to limit the potential impact of the Brown decisions. The report advocated the adoption of measures that would have declared that no student should be required to attend an integrated school and that school districts that chose to close their public schools rather than submit to integration should be empowered to raise and spend public funds for tuition grants that would defray the cost of attendance at private schools. Moreover, the report called for legislation designed to ensure that even in those districts where the public schools remained open, tuition grants would be made available in order to "prevent enforced integration ... by providing for the education of those children whose parents object to their education at mixed schools." 24

The Gray Commission report left Powell somewhat conflicted. Soon after the report was issued, Powell stated his position clearly in a letter to David J. Mays, who had served as legal counsel to the commission. On one hand, Powell expressed his opposition to the idea of tuition grants, asserting that "I am confident that [the provision of tuition grants] will not work in Richmond, and I doubt that it will work anywhere else constitutionally for any length of time." On the other, while conceding that the pupil assignment procedure described by the report had "some very troublesome aspects," Powell characterized the use of that procedure as "the best possible approach." 25

All parties to the controversy understood that the student assignment process envisioned by the Gray Commission was expected to be used to prevent or retard the integration of the public schools in Virginia. Nonetheless, many white Virginians believed that even the Gray Commission report as a whole did not provide for a sufficiently

23. Virginia Commission on Public Education, Hearings on the Nominations of William H. Rehnquist and Lewis F. Powell, Jr., of Virginia, November 11, 1955, at 8-11, https://www.gpo.gov/fdsys/granule/GPO-CHRG-REHNQUIST-POWELL/GPO-CHRG-

REHNQUIST-POWELL-7-4-14 (last visited Mar. 31, 2019).

24. Id.

25. Letter from LFP to David J. Mays, December 1, 1955, Box 250, Folder 13, Lewis F. Powell Papers, Washington and Lee University (hereinafter LFP Papers). 
aggressive response to the decisions of the Supreme Court in Brown I and Brown II. Thus, on February 24, 1956, Byrd called for "massive resistance" to the idea of integrating the public schools. Supporters of this concept argued that the state could legitimately "interpose" its authority to prevent unconstitutional interference by the federal government with local prerogatives - a theory that called to mind the concept of nullification that had at times been deployed unsuccessfully by Southerners prior to the Civil War. ${ }^{26}$

In August, 1955, the state legislature adopted a series of measures designed to implement the policy of massive resistance. ${ }^{27}$ Unlike the Gray Commission proposals, under the new program, control over the placement of students was transferred to a state Pupil Placement Board, which was composed of members who were staunchly opposed to even token integration. The legislature also required the state to withdraw funding from any local school district that attempted to desegregate its classrooms and to close the public schools in those districts. Other legislation provided for the use of tuition grants to allow students to attend segregated private schools in districts where the public schools were no longer open.

Although he made no public comment on the desegregation controversy, in private communications with other members of the political establishment, Powell made no secret of his personal opinion of these measures. While he was in general a loyal supporter of the Byrd organization at the time that Brown I was decided, Powell strongly opposed the idea of massive resistance, characterizing the concept as "legal nonsense" and "a doctrine of chaos-not of law." 28 At one point, Powell made tentative arrangements to have his assault on interposition published in the American Bar Association Journal. However, after consultations with the Hunton, Williams attorneys who were representing Prince Edward County in the ongoing desegregation litigation, he withdrew the proposal and made no other public comment on massive resistance. ${ }^{29}$

In theory, of course, Powell might have taken the moral high ground and refused to make any concessions to supporters of the position taken by the Byrd organization. However, he and the other members of the school board took the view that such an approach

26. JEFFRIES, supra note 6, at 137-38.

27. These measures are described in Jeffries, supra note 6, at 136.

28. Id. at 149 .

29. Id. at $149-50$. 
would have had a disastrous impact on the Richmond public schools. Indeed, as Powell observed later, the school board believed that, given the existing state laws and climate of public opinion in Virginia in the period immediately following the Brown decisions, "had we attempted to integrate the schools [during this period] this would have resulted in closing the schools." ${ }^{30}$ Moreover, such fears were by no means unfounded; for example, in 1958, the governor of Virginia ordered the closure of the public schools in the cities of Charlottesville and Norfolk after federal courts mandated the desegregation of the schools in both districts. ${ }^{31}$

By contrast, at least in the abstract, Powell and the other members of the Richmond school board had more options in the wake of two judicial decisions that were handed down in January, 1959. In James $v$. Almond, a three-judge federal district court held that the state could not constitutionally close the Norfolk public schools in order to avoid desegregation, declaring that

the Commonwealth of Virginia ... cannot act ... to close one or more public schools in the state solely by reason of the assignment to, or enrollment or presence in, that public school of children of different races or colors, and, at the same time, keep other public schools throughout the state open on a segregated basis. ${ }^{32}$

Although the Almond court itself explicitly left open the possibility that the state could withdraw its support from all of the public schools in the state, on the same day, in Harrison v. Day, the Virginia Supreme Court foreclosed this option, concluding that section 129 of the Virginia constitution imposed a "mandatory duty" on the state legislature to fund a public school system. ${ }^{33}$

Faced with this new reality, on February 5, 1959, Virginia Governor J. Lindsay Almond, Jr. established a new commission chaired by state senator Mosby Perrow, Jr. and charged that commission with the task of reformulating the state's approach to the issue of desegregation. Some staunch opponents of integration urged the commission to recommend that the state repeal section 129. They argued that this change in the state constitution would pave the way for the elimination of state support for public schools and the establishment

\footnotetext{
30. Id.

31. Id. at $136-37$.

32. 170 F. Supp. 331, 337 (E.D. Va. 1959) (per curiam) .

33. 106 S.E.2d 636 (1959).
} 
of a system of private segregated academies organized on a local basis and supported by tuition grants appropriated from state funds. ${ }^{34}$

In a March 10 letter to Byrd, Powell urged him not to embrace this proposal. ${ }^{35}$ Powell's opposition to the repeal movement was not based on support for the concept of desegregation. Instead, arguing that the elimination of state funding of public education would be unwise and that, if section 129 were repealed, "any system of private schools supported directly or indirectly with state funds would inevitably go down before the federal court," 36 he insisted that "if the unhappy choice becomes inevitable (as it apparently will) between the abandonment or emasculation of public education or some integration, I believe that Virginia must choose the latter." ${ }^{37}$

But at the same time, Powell also suggested that the state adopt measures that would, in his words, "ameliorate or retard integration." He gave as one example the pupil assignment plan that had been created by the Pearsall Committee in North Carolina. ${ }^{38}$ Much like the regime that had been proposed by the Gray Commission, the Pearsall Plan vested the power to assign students in local school boards, which in turn were expected to make their decisions based on "natural racial preference and the administrative determination of what is best for the child." 39

The practical consequences of this approach were entirely predictable. After the Pearsall plan was adopted, many school boards refused to allow any African-American students to transfer to previously all-white schools, while other school boards allowed only token desegregation of local schools. ${ }^{40}$ Thus, Powell's embrace of this plan can only be viewed as a reflection of a belief that the officials charged with the administration of the public schools in Virginia should, if possible, act to minimize the impact of formal desegregation on the actual racial composition of the schools in Richmond and elsewhere.

\footnotetext{
34. LFP to Harry Byrd, March 10, 1959, Box 6, Folder 5 LFP Papers supra note 25, at 1.

35. Id.

36. Id. at 3 .

37. Id. at $1-2$.

38. Id. at 4 .

39. Pearsall Committee, The Pearsall Plan to Save Our Schools, UNC GREensboro, http://libcdm1.uncg.edu/cdm/ref/collection/CivilRights/id/533 (last visited April 8, 2019).

40. See generally WALKER, supra note 22, at Ch. 2. (discussing the evolution and impact of the Pearsall Plan).
} 
Nonetheless, Powell believed that the issue of desegregation was only one of the factors that should be considered in making more general policy judgments regarding the proper functioning of the Richmond school district as a whole. Soon after he had dispatched his letter to Byrd, this point was clearly illustrated by the role taken by Powell in the discussions of a plan to build two new high schools to meet the needs of the city's burgeoning student population. The school board had proposed to locate the new schools in white neighborhoods that were close to areas with growing AfricanAmerican populations. However, when the board sought funding for the project from the Richmond city council, some members of the council opposed the request on the ground that building new schools at the proposed locations would facilitate integration. ${ }^{41}$

Powell, on the other hand, sought to characterize the impact of the new high schools quite differently. In his first public comment on the dispute over desegregation, he observed that some integration had become inevitable. He contended that, given this reality, "the new schools would appreciably improve both the short and long range prospect for minimizing the impact of integration." He asserted that the new schools themselves could be reserved for white children, which would in turn allow other facilities currently used by whites to be freed for use in educating African-American children. In contrast, he claimed, the failure to build the new schools would in time result in greater overcrowding at African-American schools, thereby increasing the pressure for integration. Powell also took the opportunity to declare that "we foresee no substantial integration in the elementary schools in Richmond." 42 Powell's defense of the school board proposal apparently mollified the supporters of segregation, and the funding for the project was approved by the council.

More than two decades later, Powell claimed in a private memorandum to his children that it was necessary to publicly express his opposition to desegregation in order to obtain approval of the necessary funding from the city council. ${ }^{43}$ However, the evidence does not support the suggestion that, if given the option in 1959, Powell would have moved aggressively to desegregate the Richmond public

\footnotetext{
41. JEFFRIES, supra note 6, at 155 .

42. Powell Outlines Views of School Board, RichMOnd TiMEs DisPATCH, May 7, 1959, at $5-6$.

43. "Desegregation Era-Interposition/Massive Resistance," Memorandum from LFP to my Children, August 23, 1983, p. 2, LFP Papers, Box 1, Folder 22.
} 
schools. Instead, both Powell's letter to Byrd and his subsequent actions plainly indicate that, at least at this point in his life, the future Supreme Court Justice remained hostile to the prospect of substantial integration of the Richmond schools.

In 1960, this attitude was reflected in the Richmond school board's internal discussions of a decision to attempt to convert Chandler Junior High School to a school serving African-Americans of both junior and senior high school age. At the time that the conversion was under consideration, Chandler was a school for white children that was located more than two miles south of the site of the new John Marshall High School and was near the northern border between Richmond's African-American and white residential neighborhoods. The main impetus behind the effort to convert the school was the need to provide facilities to accommodate the growing number of minority students attending the city schools. ${ }^{44}$

Prior to 1960, a number of other previously all-white schools had been converted for the same reasons. The members of the school board believed that, once the new John Marshall High School was completed, it could accommodate the white students who would otherwise have been assigned to Chandler, and that the conversion of Chandler would be the least expensive method of relieving the overcrowding that plagued a number of other African-American schools in Richmond in 1960. In addition, however, the school board saw the conversion of Chandler as an integral part of a strategy that was designed to limit the extent of integration in the Richmond school district more generally. ${ }^{45}$

The view that the conversion would in fact limit integration was at least implicitly based on a number of assumptions. First, in 1960, the school board and its staff clearly believed that they would at some point be ordered by a federal court to abandon the policy of maintaining schools that were formally segregated by race. Second, they apparently believed that any desegregation order would probably be based upon geographical principles. Finally, the school board assumed that the African-American population of Richmond would continue its historical pattern of expanding northward within

44. "Chandler High School," Memorandum to Members of the Richmond School Board from H. I. Willett, February 18, 1960, LFP Papers, Box 250, Folder 14; Memorandum to LFP from Assistant Superintendents Richmond Public Schools, February 22, 1960, id.

45. Memorandum from Assistant Superintendents Richmond Public Schools, supra note 44 , at 2 . 
the city. ${ }^{46}$ Thus, although the site chosen for John Marshall was well north of the areas occupied by the African-American community in 1959, many residents of Richmond (including the members of the school board itself) believed that significant numbers of AfricanAmerican families would move closer to the new school within a relatively short period of time.

Given these assumptions, from the perspective of those who, like Powell, wished to limit the scope of integration, the strategic advantages of the proposed Chandler conversion were clearly apparent. Unlike the new site of John Marshall, Chandler was located on the northern edge of the territory already populated by AfricanAmerican families. Therefore, in 1959, from a purely geographical perspective, all high school students from that community were living closer to Chandler than to the John Marshall site. Moreover, most African-Americans would continue to be in closer proximity to Chandler for a considerable time even after the residential boundaries of their community spread northward.

As a result, the school officials in Richmond believed that, if at some point in the future a federal judge ordered students to be assigned purely on the basis of geography, the conversion of Chandler to an African-American school serving both junior and senior high school students "would be strategically located to protect the new John Marshall High School [which was itself designed to serve grades eight through twelve] from massive integration." Conversely, the school board thought that unless Chandler was converted, the only cure for the overcrowding at existing African-American schools would be to transfer some African-Americans from overcrowded facilities to underutilized white schools and that, without conversion, Chandler itself would become vulnerable to "massive" integration. ${ }^{47}$

The members of the school board also viewed the conversion of Chandler as a crucial element in the board's defense against a class action lawsuit that had been filed in September, 1958, on behalf of African-American students who had been denied the opportunity to attend white schools in Richmond. A majority of the AfricanAmerican plaintiffs who were seeking to transfer wished to attend Chandler. Moreover, school officials understood that, in order to

46. Memorandum from Thomas C. Little to H. I. Willett, February 18, 1960, LFP Papers, Box 250, Folder 14.

47. Memorandum, Assistant Superintendents to LFP, supra note 44, at 1. 
prevail in the lawsuit, at the very least they would need to claim that African-Americans had access to equal educational opportunities in the city public schools, a position that would be much more difficult to maintain if the existing African-American schools remained substantially overcrowded. Thus, in a February 22, 1960 memorandum to Powell, the assistant superintendent of the Richmond schools observed that, if Chandler were not converted to use by AfricanAmerican students, "there could be no immediate relief of the crowded conditions in Negro schools except through integration" 48 and "it is feared that the case in the [f] ederal court would be jeopardized." ${ }^{49}$

Despite these considerations, the proposal to convert Chandler created a political firestorm. Although in the short term the conversion would have relieved the overcrowding in the city's African-American schools, some Richmond civil rights leaders complained that the very idea of conversion derived from the same basic concept of segregated schools that had been condemned in Brown. ${ }^{50}$ However, much of the opposition came from an entirely different quarter: white residents who lived near Chandler and were intent on preventing the spread of the African-American community into their neighborhoods.

These residents believed that the creation of a school for African-Americans near the existing boundary would incentivize African-Americans to attempt to purchase property on the all-white "Northside," which was also near Chandler. The school board itself had concluded that this area would eventually become inhabited by African-Americans in any event. ${ }^{51}$ However, many whites who lived near Chandler disagreed. Thus, for example, while conceding in a letter to Powell that "the School Board cannot control or prevent ... population shifts," one opponent of the conversion observed that "[the board] can speed or force them" and insisted that "that is exactly what the decision to convert Chandler would do." ${ }^{52}$

The dispute over the proposed conversion came to a head at a public meeting on February 24, 1960, attended by nearly 1,400 people. The crowd was dominated by whites from the Northside, and a

\footnotetext{
48. Id. at 1 .

49. Id. at 2 .

50. JEFFRIES, supra note 6, at 157-59.

51. "Chandler High School," supra note 44, at 3.

52. W. F. Maldeis to LFP, March 22, 1960, LFP Papers, Box 250, Folder 14.
} 
number of the speakers emphasized what they viewed as the potential impact of the conversion on the geographical expansion of the African-American community into their neighborhood. By contrast, when civil rights leader Oliver $\mathrm{H}$. Hill rose to advocate integration rather than conversion, Hill was subjected to what he later described as "an uproar of boos, catcalls and epithets" and was allowed to continue only after Powell stood beside him and insisted on the restoration of order..$^{53}$

In the face of this vocal opposition, the school board voted to defer the conversion of Chandler in order to allow for "the opportunity, without haste or political pressure, for calm and objective reconsideration of all possibilities." In its public statement announcing the decision, the board reiterated its view that "the conversion of Chandler should minimize the integration problem which faces Richmond." ${ }^{54}$ At the same time, however, the board insisted that "the plan to convert was based entirely on unrelated considerations." $" 55$

Powell's endorsement of the Pearsall Plan and support for the Chandler conversion were consistent with the position that he had originally taken on the Gray Committee proposals in 1955. Moreover, the removal of the possibility that desegregation would lead to closure of the Richmond public schools did nothing to change the basic structure of the city school system during the remainder of the time that Powell served as the chair of the school board. Each of the schools in the system was explicitly labeled either "white" or "Negro," and although the state Pupil Placement Board remained formally responsible for assigning students, until August 15, 1960, the state board uniformly assigned white students to white schools and African-Americans to "Negro" schools. On that date, the board allowed two African-American students to enter Chandler, thereby rendering the debate over conversion moot. ${ }^{56}$

53. Sandra Day O'Connor, A Tribute to Lewis F. Powell, Jr., 101 HARV. L. REV. 395, 41011 (1987).

54. Decision Postponed on Chandler School, RICHMOND TIMES-DisPATCH, Feb. 25, 1960, at 1.

55. Id. at 4 .

56. Robert A. Pratt, The Color of THEIR Skin: EducAtion AND RACE IN RICHMOND, VIRGINIA, 1954-1989 25 (1992). 


\section{The Ongoing Struggle Over the Desegregation of the Richmond Schools}

The dispute over the conversion of Chandler marked Powell's last confrontation with the issue of desegregation as a member of the Richmond school board. In January, 1961, he resigned from that position after accepting an appointment to the Virginia State Board of Education and thereafter had no official input into the policy decisions that determined the course of desegregation in the city. Nonetheless, Powell retained a keen interest in the affairs of the school system in general and the problem of desegregation in particular. In 1963, he was one of a number of prominent attorneys who were asked by Attorney General Robert F. Kennedy to discuss the prospects for improvement in race relations in their local communities. Powell's reply once again reflected his attitude toward the basic idea of school desegregation. ${ }^{57}$

The events that had taken place in the years immediately following Powell's departure from the school board provided the backdrop for his assessment of the situation. As already noted, during this period, the state Pupil Placement Board had retained the authority to make student assignments in the city schools. Moreover, even after the admission of African-Americans to Chandler in 1960, until 1963, every school in the city continued to be labeled either "white" or "Negro" by the city school board, and also drew students from a designated attendance area. Absent a specific request to the contrary, each student was initially assigned to the school which corresponded to his race and the attendance zone in which he or she lived, and after having graduated from their elementary schools, students were routinely assigned to junior high schools and high schools associated with the same race. In addition, African-American students who wished to transfer to white junior or senior high schools were required to meet academic standards that were not applied to white students from the same attendance area. As a result, during the 1962 school year, of the over twenty-three thousand AfricanAmerican students in the Richmond public school system, only thirtyseven attended schools with white students. ${ }^{58}$

After this system was found unconstitutional in federal court, the Richmond school board formally changed its policy. In March, 1963,

57. LFP to Robert F. Kennedy, July 23, 1963, LFP Papers, Box 209, Folder 3.

58. Bradley v. Sch. Bd. of the City of Richmond, 317 F.2d 429, 432 (1963). 
the board adopted a series of resolutions that required each student entering the system to affirmatively state which school he wished to attend, and to repeat the process at the time that he entered junior high school and high school. The resolutions also provided for free transfers between schools. ${ }^{59}$ While eliminating the formal consideration of race from the process, in practice the new system had only a very limited impact on the demographic makeup of the individual schools. Thus, in the fall of 1963, only 312 AfricanAmerican students attended school with their white counterparts in Richmond. ${ }^{60}$ As a result, in his response to Kennedy's request, even Powell was forced to acknowledge the fact that the desegregation of the city schools was "naturally not progressing as rapidly as Negro leaders would wish." He also noted that the actions of the school board were being challenged in federal court. ${ }^{61}$

Despite this lack of concrete results, Powell's letter to Kennedy described the situation in Richmond as "generally satisfactory." Apparently referring to the admission of the two African-American students to Chandler in 1960, he noted that the process of desegregation had begun during the period in which he had chaired the school board. In addition, Powell observed that "each year the extent of integration increases" and predicted that "as long as this is accomplished gradually and without too much public pressure, there will be a large measure of acceptance by whites." ${ }^{62}$

This assessment aptly reflected Powell's attitude toward the desegregation of the Richmond public schools more generally. Unlike the supporters of massive resistance, by the late 1950s, he had (albeit reluctantly) demonstrated a willingness to accept the reality that formal segregation would have to be abandoned. However, Powell had no real commitment to the ideal of integration in practice. Instead, he firmly believed that, in deference to the sensibilities of white residents of Richmond, the process of integration should proceed only at a pace that Powell characterized as "gradual," but that most objective observers would more likely have described as glacial.

\footnotetext{
59. Id.; PRATT, supra note 56, at 36.

60. PRATT, supra note 56, at 36.

61. LFP to Robert F. Kennedy, supra note 57 , at 1.

62. Id.
} 


\section{Powell and the Prince Edward County Schools}

The same attitude that had marked his approach to desegregation in Richmond was also reflected in Powell's actions when, as a member of the state board of education, he was called upon to deal with the fallout from the ongoing struggle over desegregation in Prince Edward County. After the collapse of statewide massive resistance in 1959, the government authorities in Prince Edward County had closed the county public schools to avoid submitting to even token desegregation. The public schools in the county remained closed until they were ordered reopened by the Supreme Court in 1964. In the interim, the white students in the county attended segregated private academies that had been created to replace the public schools.

At first, the private academies were financed in part by state tuition grants and also received additional financial support from the county government. However, in August, 1961, a federal court issued an order barring state officials from "receiving, processing or approving applications for state scholarship grants from persons residing in Prince Edward County so long as the public schools of Prince Edward County remained closed." 63 Thus, from 1961 through 1963, the white students attending the segregated academies were forced to finance their educations entirely from private funds.

Ironically, the Supreme Court's 1964 decision in Griffin v. County School Board, ${ }^{64}$ which required that the public schools of Prince Edward County be reopened, gave new hope to the proponents of tuition grants. On its face, Griffin was a major defeat for the remaining supporters of massive resistance. But by ordering that the schools be reopened, the decision also appeared to remove the predicate for the ban on the payment of tuition grants. Thus, after Griffin was decided, Virginia's attorney general expressed the view that the prohibition imposed by the earlier court order was no longer in force. Against this background, although Powell had privately complained that "Prince Edward [County] is increasingly becoming a serious reflection on the good name of Virginia," on July 1, 1964, he joined the other members of the state board of education in approving applications for the payment of tuition grants for the

63. Allen v. Cty. Sch. Bd. of Prince Edward Cty, 198 F. Supp. 497, 504 (E.D. Va. 1961) (emphasis added).

64. 377 U.S. 218 (1964). 
previous school year, notwithstanding the fact that the deadline for applying for such grants had passed and that in $1963 .{ }^{65}$

While James Jeffries argues that Powell saw the vote as nothing more than a decision to effectuate the will of the legislature ${ }^{66}$ Powell's communications with Harry Byrd suggest a different explanation for his support of the motion to extend the deadline. Admittedly, in 1955, Powell had been flatly opposed to the use of public funds to support tuition grants. By 1959, however, his views had apparently changed. Clearly referring to localities such as Prince Edward County, in the same letter in which he advocated the adoption of a Pearsall-type plan to deal with the situation in places such as Richmond, Powell also observed that "there are many areas in Virginia that will simply not tolerate integration," and contended that "it is . . necessary to provide these communities with some acceptable alternative" by "provid[ing] the means for local communities and possibly individuals to experiment with alternatives." ${ }^{67}$ Thus, Powell suggested that it would be appropriate for the state to provide funds for tuition grants that would predictably be used to support the establishment of segregated private schools in those areas, notwithstanding his conviction that "such schools will [not], on the average be anything like as satisfactory as state supervised public school education." ${ }^{68}$

Considered against the background of his other actions, Powell's willingness to countenance the use of tuition grants in this context should not be construed as reflecting approval of the tactics used by jurisdictions such as Prince Edward County in an effort to avoid desegregation. Instead, he apparently believed simply that, given the reality of the attitude of whites toward desegregation, providing tuition grants for school-aged children would be the best of a set of bad options available to the state government. Powell's decision to approve the applications for tuition grants in 1964 may well have reflected a similar calculation.

Whatever considerations in fact influenced Powell's vote, the practical import of his choice was clear. By supporting the waiver of the application deadline, he voted to reduce the financial cost to white students of the decision to abandon the public school system in order to avoid attending schools with African-Americans and also implicitly

65. JEFFRIES, supra note 6 , at 176.

66. Id. at $176-77$.

67. LFP to Harry F. Byrd, March 10, 1959, supra note 34, at 3.

68. Id. at 4 . 
refused to condemn such resistance to desegregation. Thus, at the very least, Powell's vote on the tuition grant issue once again demonstrates that during the mid-1960s, he had no particular interest in advancing the process of integrating the schools.

\section{E. Powell and School Busing}

In 1970, Powell rejoined the public debate over desegregation during the Supreme Court's consideration of Swann v. CharlotteMecklenburg Board of Education. ${ }^{69}$ Neither the city of Richmond nor the state of Virginia was directly involved in the Swann litigation. Nonetheless, it was the evolving situation in the Richmond school system that provided the backdrop for Powell's participation in the case.

In the late 1960s, the placement of students in the Richmond schools was governed by the freedom of choice plan that had been adopted by the Richmond school board in 1962, ultimately accepted by the plaintiffs in the Bradley litigation, and finally implemented during the 1966-67 school year. As already noted, under this plan, the parents of the students in the public schools were allowed to have their children attend any public school in the city, provided only that the curriculum was suitable and space was available. However, as in most jurisdictions, the advent of freedom of choice had only a limited impact on the racial composition of the individual public schools in Richmond.

A variety of factors contributed to this reality. Residential neighborhoods in Richmond remained highly segregated, and in many cases African-Americans were reluctant to venture into other parts of the city to attend schools where the other members of the student body often resented their presence. White students were even more reluctant to travel significant distances to attend schools with large African-American populations. In addition, because Richmond did not provide free transportation for public school students, those who did not attend their neighborhood schools and relied on public transportation often incurred substantial financial costs. ${ }^{70}$

The impact of the combination of residential segregation and the ongoing preference of students for their neighborhood schools was reflected in the continuing racial imbalance in the individual schools.

\footnotetext{
69. 402 U.S. 1 (1971).

70. PRATT, supra note 56 , at 41-55.
} 
During the 1969-70 school year, the student bodies of seven of the seventeen secondary schools in Richmond were at least eighty-eight percent African-American, and in five of the other schools, the student body was more than ninety percent white. Similarly, twentyone of the forty-four elementary schools in the city were at least ninety percent African-American, while seventeen of the remaining twenty-three schools were at least eighty-six percent white. ${ }^{71}$

However, the Supreme Court's 1968 decision in Green v. New Kent County Board of Education ${ }^{72}$ dramatically changed the jurisprudential landscape of the struggle over desegregation. Green came to the Court as a challenge to the student assignment policy of New Kent County, a small rural county in Virginia that had operated one school providing elementary and secondary education for all white students and one school providing the analogous services to all AfricanAmerican students until $1965 .^{73}$ In that year, in response to a newly filed law suit and the threat of losing federal funding, the school district adopted a freedom of choice plan, which essentially allowed students in the district to choose to attend either of the two schools. ${ }^{74}$ By 1968, fifteen percent of the county's African-American students had chosen to attend the formerly all-white school, but no white students had chosen to attend the formerly all-African-American school. ${ }^{75}$ Despite these results, the plan met the guidelines that had been established by the Department of Health, Education and Welfare, which was responsible for administering the relevant portions of the Civil Rights Act. ${ }^{76}$

Nonetheless, the Supreme Court unanimously held that the freedom of choice plan was not an adequate remedy for past segregation. Justice Brennan's opinion for the Court clearly reflected the impact that Southern intransigence had had on the thinking of the justices. Beginning with the premise that, under Brown, "school boards such as [that of New Kent county were] clearly charged with the affirmative duty to take whatever steps might be necessary to convert to a unitary system in which racial discrimination would be

\footnotetext{
71. Id. at 46 .

72. 391 U.S. 430 (1968).

73. Id. at 433 .

74. $I d$.

75. Id. at 441 .

76. U.S. Office for Civil Rights, HEW, Policies on Elementary and Secondary School Compliance with Title VI of the Civil Rights Act of 1964, 33 Fed. Reg 4955 (1968).
} 
eliminated root and branch," ${ }^{77}$ Brennan noted the refusal of the New Kent County School Board to take any steps toward disestablishment of its dual school system in the years immediately following the decision in Brown. Observing that "this deliberate perpetuation of the unconstitutional dual system can only have compounded the harm of such a system," 78 Brennan wrote that "the time for mere "deliberate speed" has run out" " and declared that "the burden on a school board today is to come forward with a plan that promises realistically to work, and promises realistically to work now." 80

In Green itself, the implications of this requirement for the formulation of a remedy were relatively clear. As Justice Brennan observed in a footnote, because housing in the county was not segregated by race, "the elimination of the dual school system and the establishment of a 'unitary, nonracial system' could be readily achieved with a minimum of administrative difficulty by means of geographic zoning." ${ }^{81}$ By contrast, in urban areas such as Richmond, which were marked by segregated housing patterns, a simple requirement that students be assigned to the schools nearest their homes often in reality produced schools whose student bodies in fact were either overwhelmingly white or overwhelmingly AfricanAmerican. Moreover, the situation was further complicated by the fact that, in May, 1969, a state court had approved the annexation of an overwhelmingly white portion of nearby Chesterfield County whose residents thereafter accounted for nearly twenty percent of the population of the newly-expanded city. ${ }^{82}$ Thus, in 1969, the precise implications of the Green standards for the configuration of the Richmond public schools were not entirely clear.

Against this background, on March 10, 1970, the plaintiffs in Bradley filed a motion requesting the district court to order the school board to adopt a plan that would create greater racial balance in the Richmond schools. ${ }^{83}$ After District Judge Robert R. Mehridge, Jr. ordered the school board to provide a plan that created a "unitary" system of public schools, the board submitted a proposal that was

77. Green, 391 U.S. at 437-38.

78. Id. at 438 .

79. Id. at 439 .

80. Id.

81. Id. at 442 .

82. The circumstances surrounding the annexation of Chesterfield County are described in detail at pp. 199-200 below.

83. Bradley, 317 F. Supp. at 558 (E.D. Va. 1970). 
devised by the representatives of the federal department of Health, Education and Welfare. ${ }^{84}$ The HEW proposal relied heavily on the concept known as "grade pairing," providing that black and white schools serving similar geographic attendance zones would be "paired" by having each school serve different grade levels. ${ }^{85}$ Mehridge, however, concluded that this proposal did not provide an adequate remedy for past segregative acts. ${ }^{86}$

Asserting that the HEW proposal was, "in essence, a neighborhood school plan," and that the proposal was "basically a zoning plan, with some clustering of schools," Mehridge observed that the drafters of the plan gave little consideration to race per se, but instead focused on issues such as "the capacity of the school buildings, the proximity of the buildings to the pupil population, and factors such as the safety hazards on the immediate approaches to the schools in relation to where the pupils lived." While conceding that "under certain circumstances [a neighborhood school plan] undoubtedly would be commendable," Judge Mehridge insisted that

by reason of the residential patterns in the City of Richmond, however, wherein there are with rare exceptions distinct White areas and distinct Black areas, a true neighborhood school plan of necessity can result only in a system in which there are Black schools and White schools and not just schools. ${ }^{87}$

Judge Mehridge buttressed this assertion by describing the impact that the implementation of the HEW plan would have had on each of the individual schools in the Richmond school district. Under the plan, African-Americans would have comprised more than ninety percent of the student body in eighteen different schools in the district ${ }^{88}$ Conversely, whites would have comprised at least eighty percent of the student body in thirteen different schools in the district. ${ }^{89}$ Moreover, in each of the ten schools located in the newly annexed area that had previously been part of Chesterfield County, the student body would have been at least eighty-nine percent white, and in nine of the ten schools, whites would have comprised at least ninety-five percent of the student body. ${ }^{90}$

\footnotetext{
84. Id. at 564 .

85. $I d$.

86. Id. at $563-65$.

87. Id. at 564 .

88. Id

89. Id.

90. Id.
} 
Faced with these objections, the school board submitted a new proposal on July 23, 1970. The revised plan provided not only for pairing, but also for other changes in student assignments, majority to minority transfers, and some free transportation of studentsprimarily middle school and high school students-who would be required to travel significant distances to reach their assigned schools. Judge Mehridge observed that the new proposal reflected a good faith effort to comply with applicable legal standards and acknowledged that the revised plan would significantly improve the racial balance of a number of schools in the Richmond system. ${ }^{11}$

Nonetheless, Judge Mehridge was not entirely satisfied with the terms of the school board proposal. Noting that the proposal left a significant number of schools either identifiably white or identifiably African-American, Judge Mehridge was particularly disturbed by the fact that the student bodies of thirteen elementary schools would remain over ninety percent African-American, while four elementary schools would be virtually all-white. Because of these issues, Judge Mehridge concluded that the school board should be required to submit a third plan within ninety days to address his concerns. At the same time, however, he recognized that no such plan could be approved in time to be implemented for the school year that was to begin on August 31, 1970. Thus, he ordered that the July 23 plan should form the basis for the assignment of students on an interim basis for the 1970-71 school year, with the understanding that permanent student placements would be based on the third plan that had yet to be submitted or approved..$^{22}$

Predictably, significant elements of Richmond's white community strongly opposed the implementation of even the interim plan. White parents sometimes complained openly about the consequences of having their children attend school with significant numbers of African-Americans, and at times whites resorted to a variety of tactics in an effort to avoid having their children attend integrated schools. In some cases, white students simply abandoned the public schools rather than attend the integrated or predominantly African-American schools to which they were assigned. Thus, the number of white students who actually enrolled in the Richmond schools for the 1970-

\footnotetext{
91. Id. at 573 .

92. Id. at 575 .
} 
71 school years was almost twenty-five percent lower than the number that had been projected. ${ }^{93}$

These events provided the context for Powell's participation in Swann - the first case in which the Supreme Court was called upon to review the propriety of a desegregation order much like that which Judge Mehridge sought to impose on the Richmond school district. Powell was the primary architect of an amicus brief that was filed in October, 1970 on behalf of the state of Virginia in Swann. ${ }^{94}$ In describing the interest of the state in the case, the brief conceded that, until 1964, any progress toward the desegregation of the public schools in Richmond and other Virginia school districts was "an unwilling march prodded by the [federal] courts." 95 At the same time, however, the brief insisted that "Virginia municipalities are [now] attempting in good faith to comply with the mandate of the Equal Protection Clause." ${ }^{\prime 96}$ Conversely, the brief asserted that the orders issued by the federal courts had created "chaotic" conditions in many school districts. ${ }^{97}$

In particular, the brief claimed that the interim order that had been issued in August by Mehridge "has resulted in major disruption to public education" and "has often led to resentment and even fear." 98 In Powell's view, the negative effects of the interim order were likely to be magnified by any final order that was based on the principles outlined in Mehridge's August opinion. Asserting that "racial balance alone was the determining factor in [the decision of the district court] in the [Richmond case]," Judge Mehridge had not given adequate weight to other factors in devising a desegregation plan. ${ }^{100}$

Powell deployed a variety of different arguments to support his contention that racial balance should not be the sina qua non of desegregation plans. First, he asserted that nothing in the Court's desegregation cases suggested that the Constitution imposed such a

93. PRATT, supra note 56 , at $49-51$.

94. Brief for the Commonwealth of Virginia as Amicus Curiae, Swann v. CharlotteMecklenburg Bd. of Educ., 402 U.S. 1 (No. 281).

95. Id. at 2.

96. $I d$.

97. $I d$.

98. Id. (footnote omitted).

99. Id. at 5 .

100. See id. at 7 (noting that "[t]he court below unduly emphasized racial balance. It also failed to recognize the relevance of the neighborhood school and the disadvantages for all races of extensive compulsory busing."). 
mandate. ${ }^{101}$ Second, noting that the demographics of cities were constantly in flux, he contended that the pursuit of racial balance would induce white families to either leave the cities or enroll their children in private schools, thereby actually encouraging the resegregation of the public schools and "accelerat[ing] the process of urban deterioration." 102

Against this background, Powell argued that the federal courts should adopt a radically different approach to desegregation cases. While conceding that racial imbalance was a factor that should be considered in crafting remedial orders in such cases, he asserted that "equal opportunity [should not] be measured purely by equality of resource application and racial balance." 103 Instead, in Powell's view, "[the] system [that] best conforms to the constitutional mandate [is one] that provides, through equal opportunity for every student, the highest level of achievement for all students of every race, compensating appropriately for any deficiencies that may have resulted from previous racial segregation." ${ }^{104}$ Similarly, the brief later declared that "the goal is the best education for all" 105 and that "what ... the school boards must seek and the courts must approve is the means to promote equal educational opportunity, regardless of race, in a system structured for the highest achievement." 106 From this perspective, the problem with racial segregation was that it was "an impediment to be removed in striving to achieve that goal." 107

The brief also insisted that, in desegregation orders, "reasonable discretion must be allowed in the assignment of pupils and the administration of a school system." ${ }^{108}$ At the same time, Powell clearly believed that, absent judicial intervention, the exercise of this "reasonable discretion" would lead to the creation of neighborhood schools and that, particularly at the elementary school level, neighborhood schools were in general most likely to advance educational achievement. ${ }^{109}$ In addition to observing that "the

101. Id. at $11-13$.

102. Id. at $14-16$.

103. Id. at 7 .

104. Id.

105. Brief for the Commonwealth of Virginia, supra note 94, at 18.

106. Id. at 19 .

107. Id. at 18 .

108. Id. at 17 .

109. See id. at 23-24 ("The unique educational advantages of the neighborhood school system, where it is administered in a manner consistent with the Equal Protection Clause, result in the accomplishment of the ultimate goal of that clause: the best possible education for all 
neighborhood unit provides for ease of access to schools for students, minimizing costs and time of travel to and from school," ${ }^{110}$ he contended that "educational effectiveness ... is dependent on the attitude of parents toward their children's education, and rationally configured systems of neighborhood schools play a vital role." ${ }^{111} \mathrm{He}$ also asserted that "[c]ommunity schools, when designed in such a way as to avoid the feelings of disaffection which attend systematic ghettoization ... foster such an active parental role because of their very accessibility." 112

Conversely, while acknowledging that busing of students had in the past been used to perpetuate segregation and remained a necessity in some rural school districts, the brief was unsparingly critical of the use of busing in pursuit of what Powell described as "rigorously uniform racial balance." ${ }^{113}$ Once again focusing primarily on elementary schools, he contended that widespread busing "removes a child from a familiar environment and places him in a strange one ... separates the child from parental supervision for longer periods of time . . undermines the neighborhood or community school, so desirable at the elementary level ... and ... adds to already strained budgetary demands." 114 Thus, while conceding that some busing might occasionally be appropriate in a desegregation plan, Powell concluded that a requirement of widespread transportation of students in the pursuit of racial balance "could be disastrous to public education." 115

Powell's brief in Swann can be analyzed from a variety of different perspectives. On one level, the argument in the brief can appropriately be viewed as the byproduct of a significant change in Powell's own attitude toward the issue of school desegregation. The brief implicitly rejected both the policy of evasion embodied in his 1959 letter to Harry Byrd and the advocacy of extreme gradualism reflected in his 1963 letter to Robert F. Kennedy in favor of a regime

children.").

110. Id. at 22-23.

111. Id. at 23 .

112. Id. at 23-24.

113. See id. at 21-22 (describing what Powell believed to be "[a] notable example of unreasonable busing" in Los Angeles).

114. Id. at 22 .

115. Id. at 11; see also id. at 24 ("Pursuit of absolute racial balance in major metropolitan areas through the use of extensive busing of students deprives the school system of the singular advantages of the neighborhood concept, and in at least this respect thwarts the attainment of equal educational opportunity."). 
in which school districts would be largely indifferent to issues of race in the assignment of students - an approach that even Thurgood Marshall might well have accepted in the late 1950s. ${ }^{116}$ Indeed, as Powell observed in the brief, the approach that he advocated in Swann fit comfortably with the language of Brown II, where the Court had suggested that what Brown I required was, among other things, "[the] revision of school districts and attendance areas into compact units to achieve a system of determining admission to the public schools on a nonracial basis ...."117

However, the political and jurisprudential context in which the Swann brief was written was far different from that of 1959 and 1963. By 1970, even in the South, few if any mainstream politicians would have explicitly advocated a policy of either formally segregating the public schools or openly attempting to evade the basic thrust of Brown I. Moreover, Green had made it clear that, in most cases, even freedom of choice plans would no longer be acceptable. ${ }^{118}$ Thus, whether or not Powell's personal feelings had changed, by 1970 the race-blind approach that he advocated in Swann was clearly the least intrusive remedial theory that had any chance of winning the support of a majority of the justices.

In any event, the dispute over school desegregation was not the only racially-charged issue in which Powell took a personal interest during his last years as a private citizen. Shortly before his appointment to the Supreme Court, Powell also became personally involved in a controversy that implicated the balance of political power between whites and African-Americans in Richmond. Not surprisingly, Powell's approach to this controversy reflected much the same attitude toward race relations that animated his argument in Swann.

116. See Mark V. Tushnet, Making Civil Rights Law: Thurgood MARshall AND THE SUPREME COURT, 1936-1961 234-35 (1994) (noting that the NAACP did not challenge many school desegregation plans because its leaders, including Marshall, "believed that Brown established the principle that school boards could not take race into account in assigning students to schools ....").

117. Brief for the Commonwealth of Virginia, supra note 94, at 12 (quoting Brown v. Bd. of Edu., 349 U.S. 294, 300-01 (1955)).

118. See Green v. Cty. Sch. Bd. of New Kent Cty., 391 U.S. 430, 440-41 (1968) ("[I]f there are reasonably available other ways, such for illustration as zoning, promising speedier and more effective conversion to a unitary, nonracial school system, 'freedom of choice' must be held unacceptable."). 


\section{F. Annexation and the Voting Rights Act}

The dispute that attracted Powell's attention to the issue of voting rights arose from the long-running effort by the city of Richmond to annex a portion of Chesterfield County, a largely suburban community that bordered the Richmond city limits. Although the annexation effort began in 1961, the officials representing Richmond and Chesterfield did not reach an agreement on the terms of the annexation until 1969. ${ }^{119}$ The state courts approved this agreement, which provided that twenty-three square miles of the county would be transferred to city jurisdiction in exchange for a payment of more than twenty-seven million dollars. ${ }^{120}$ The issues that concerned Powell involved the interaction between the annexation process and section five of the Voting Rights Act of $1965,{ }^{121}$ which prohibited "covered" jurisdictions, most of which were located in the South, from changing election procedures without first obtaining either the approval of the Justice Department or a judgment from the United States District Court for the District of Columbia declaring that the use of the new procedures would not perpetuate racial discrimination. ${ }^{122}$ In 1966, the Supreme Court rejected a challenge to the constitutionality of the preclearance requirement in South Carolina v. Katzenbach, ${ }^{123}$ and five years later, in Perkins v. Mathews, ${ }^{124}$ a majority of the justices concluded that annexations by local government were subject to the requirement. ${ }^{125}$

At one point, it appeared that the controversy over preclearance might be short-lived. Under the original Voting Rights Act, the requirement was imposed for only five years, ${ }^{126}$ and when Congress considered extending the life of section five in 1970, the proposal was opposed not only by white Southern members of Congress but also by the administration of President Richard M. Nixon. ${ }^{127}$ Initially, the

119. The complex maneuvering that ultimately resulted in the annexation of Chesterfield County is described in detail in JOHN V. MOESER \& RUTLEDGE M. DENNIS, THE POLITICS OF ANNEXATION: OLIGARCHIC POWER IN A SOUTHERN CITY (1982).

120. Id. at 123 .

121. 52 U.S.C.A. $\$ 10304($ a) (West 2018).

122. $I d$.

123. 383 U.S. 301, 308 (1966).

124. 400 U.S. 379 (1971).

125. Id. at 437.

126. Voting Rights Act of 1965, Pub.L. 89-110, Aug. 6, 1965, 79 Stat. 437, 438 (1965) (current version at 52 U.S.C.A. § 10304 (West 2018)).

127. J. Morgan Kousser, The Strange, Ironic Career of Section Five of the Voting Rights Act, 1965-2007, 86 TEX. L. REV. 667, 686-88 (2008). 
House of Representatives approved a voting rights bill that would have allowed the preclearance requirement to lapse. ${ }^{128}$ However, both the House and the Senate ultimately passed what was to become the first of a series of extensions of the provisions of section five, and Nixon chose to sign the bill into law. ${ }^{129}$

These developments provided the backdrop for the dispute over the Chesterfield annexation. In 1969, apparently believing that such transactions were not subject to section five, Richmond city officials had made no effort to have the annexation precleared by the Justice Department. ${ }^{130}$ However, on January 28, 1971, after the preclearance requirement had been extended for an additional five years and Perkins had made it clear that annexations were subject to the requirement, the Richmond city attorney sent a letter to the United States Attorney General asking whether the principles established in Perkins applied retroactively to annexations that had been completed prior to the decision. ${ }^{131}$

On May 7, 1971, the Justice Department sent the Richmond authorities a letter that formally objected to the Chesterfield annexation. ${ }^{132}$ The letter focused on the impact of the annexation on the demographics of the city of Richmond as a whole. Prior to the annexation, the population of Richmond had been fifty-two percent African-American. By contrast, since the population of the area acquired from Chesterfield County was virtually all white, AfricanAmericans comprised only forty-two percent of the city's postannexation population. Thus, the Justice Department observed that the addition of the new territory "inevitably tends to dilute the voting strength of black voters." Against this background, the letter also suggested that "you may ... wish to consider means of accomplishing annexation which would avoid producing an impermissible adverse racial impact on voting, including such techniques as single member districts." 133

It was the latter suggestion that provoked a response from Powell. Powell had been the chairman of the Charter Commission that

128. H.R. 4249, 91st Cong. (1969).

129. Voting Rights Act Amendments of 1970, Pub. L. No. 91-285, 84 Stat. 314 (codified as amended in scattered sections of 52 U.S.C.A.).

130. MOESER \& DENNIS, supra note 119, at 146.

131. Id.

132. 149-50.

133. MOESER \& DENNIS, supra note 119 , at $150-51$. 
established the existing form of the Richmond city government, and he had come away from the experience firmly convinced of the superiority of at-large elections to single member districts in municipal governments. ${ }^{134}$ The strength of this conviction emerged clearly in a memorandum that Powell submitted to the Justice Department on August 9, 1971. ${ }^{135}$

Powell did not formally represent the city of Richmond in its dealings with the Justice Department. Instead, he purported to speak only as an "interested citizen and the former Chairman of the [Charter Commission]."136 Nonetheless, his memorandum strongly urged the Justice Department to grant its approval to the Chesterfield annexation. ${ }^{137}$

The memorandum began with a discussion of the standards that Powell believed that the Justice Department should apply in considering annexations in jurisdictions that were subject to the preclearance requirement. ${ }^{138}$ Observing that almost any annexation would change the ratio of white voters to African-American voters, Powell contended that "the fact that voting ratios are changed by annexation should be immaterial [to the question of whether a proposed annexation should be granted preclearance.]"139 $\mathrm{He}$ argued that instead, "the test should be whether the predominate [sic] purpose [of the annexation] is racial and discriminatory." 140

Against this background, the memorandum next turned to a discussion of the basic policy considerations implicated by the concept of annexation generally and in Virginia specifically. Powell noted that in Virginia, cities were not included in any county. ${ }^{141}$ Instead, city and county governments were entirely separate political entities, and cities had often made efforts to acquire territory from surrounding counties during the twentieth century. ${ }^{142}$ Indeed, the city of Richmond itself

134. See LFP to Potter Stewart, February 28, 1980, LFP Case File, City of Mobile v. Bolden, No. 77-1844.

135. "City of Richmond-Chesterfield Annexation,” August 9, 1971, LFP Papers, Box 118, Folder 9.

136. Id. at 1 .

137. Id. at 19 .

138. Id. at $4-7$.

139. Id. at 6 .

140. Id. at 6-7.

141. Id. at 7-11.

142. Id. at 9-10. 
had annexed nearby territory on ten separate occasions prior to 1971. ${ }^{143}$

Powell vehemently rejected any suggestion that the annexation process was intended to provide cities with a mechanism to discriminate against African-American voters. Instead, he characterized annexations as a natural response to population movements over time. He observed that "as a city develops a peripheral metropolitan, suburban area, there comes a time when it is economically necessary to recapture portions of such [an] area" because "the suburban developments ... deprive the city of essential revenues from people who enjoy all the benefits of the metropolitan area." ${ }^{144}$ Powell contended that, given this reality, "a Virginia city must expand its boundaries periodically or the social and economic consequences-for blacks and whites alike-are disastrous." ${ }^{145} \mathrm{He}$ also insisted that the Chesterfield annexation in particular was justified by "social and economic reasons [that were] deemed necessary for the citizens involved" and that there were no "racial overtones" in those reasons. ${ }^{146}$ Instead, he contended that "if there had not been a single black voter in the City of Richmond, the annexation would have been equally necessary and in the public interest." ${ }^{147}$

Indeed, Powell asserted that one of the obstacles to annexation had been the fear among white residents of Chesterfield that their children might be bussed to predominantly African-American schools as part of a court-ordered desegregation plan. ${ }^{148}$ Conversely, he contended that "if the reasoning of the Supreme Court in [Swann] be accepted, the blacks and their children (because of the effect on desegregation of schools) have far more to gain from this annexation than the whites." 149

The memorandum then turned to the suggestion that the system of at-large elections should be replaced by single member districts in order to prevent the reduction of the political power of the AfricanAmerican community under the post-annexation regime. Arguing that

143. Id. at 10 .

144. Id. at 9 .

145. Id. at 10 .

146. Id. at 12 .

147. Id. at 17 .

148. Id. at 12 .

149. Id. at $17-18$. 
"a municipal government (unlike the state or the federal government) is strengthened by at-large elections," Powell insisted that the Richmond Charter Commission had followed the "prevailing view of the best scholars of municipal government" when it had chosen to adopt the at-large system in $1947 .{ }^{150}$ Observing that under the at-large system "each citizen is ... 'represented' by all members [of the city council] and not merely by those from his particular ward," he contended that "decisions are [therefore] made, as they should be, on the basis of the best interest of the city as a whole." ${ }^{151} \mathrm{He}$ also asserted that "'log-rolling' and 'trade-offs,' inevitable and destructive in a ward system, are rarely found where each councilman is elected by an at-large vote." 152

Powell also rejected the claim that the transition to single member districts was necessary to preserve the political influence of AfricanAmericans in a post-annexation Richmond. While conceding that "some black leaders" now advocated the establishment of single member districts, ${ }^{153}$ Powell observed that the African-American leadership had generally supported the creation of the at-large system when it was first proposed in $1947 . .^{154}$ In addition, he noted that in recent years there had been "substantial and increasing black participation" in the Richmond city government, and that even after annexation African-Americans would be the "single most cohesive and influential 'block' of voters in the city" and thus that "no politician could-even if he desired-afford to ignore their views or their welfare." $" 155$

Like his brief in Swann, Powell's assessment of the annexation process and the political situation in Richmond can be evaluated from a variety of different perspectives. His claim that the concept of annexation had not traditionally been associated with racial considerations found considerable support in the historical record. Between 1906 and 1942, the city had annexed substantial portions of the neighboring Henrico and Chesterfield counties on four separate occasions, with each annexation having significantly expanded both the geographical size and population of the city. As Powell noted in

\footnotetext{
150. Id. at 14 .

151. Id.

152. Id. at $14-15$.

153. Id. at 16 .

154. Id. at 15 .

155. Id. at 16 .
} 
his memorandum, racial issues do not appear to have played an important role in the consideration of any of these successful efforts to expand the limits of the city. For example, although the acquisition of almost seventeen square miles of land from Henrico County in 1942 had added significantly to the total population of Richmond, the racial composition of the population of the city had not changed significantly between 1940 and $1950 .{ }^{156}$

But at the same time, Powell substantially understated the role played by racial considerations in the specific annexation that was being considered by the Justice Department in 1971. As early as 1960, the issue of race had begun to emerge as a major factor in determining the success or failure of the city's attempts to acquire additional land and population. ${ }^{157}$ As African-Americans continued to move from the countryside to the city and substantial numbers of affluent whites fled the city for the suburbs, the demographics of Richmond changed substantially. While African-Americans made up only thirty-two percent of the population of Richmond in 1950, by 1960, forty-two percent of Richmond residents were AfricanAmerican. ${ }^{158}$ Moreover, in the absence of changes in the boundaries of the city, the trend was expected to continue, with AfricanAmericans projected to form a majority of the population in the city before the end of the decade. ${ }^{159}$

As African-Americans began to comprise a larger percentage of the Richmond population, the political importance of the city's African-American community was enhanced as well. Although whites continued to dominate the city government until the 1960s, the increase in African-American influence had begun with the overhaul of the City Charter to which Powell referred in his memorandum. Prior to that date, the city had been governed by a council whose members were selected from single member districts that were gerrymandered to ensure that only whites would be elected to the council. ${ }^{160}$ By contrast, the new charter required all members of the council to be selected on an at-large basis. ${ }^{161}$ Although only one African-American was elected under this system prior to 1964 , by

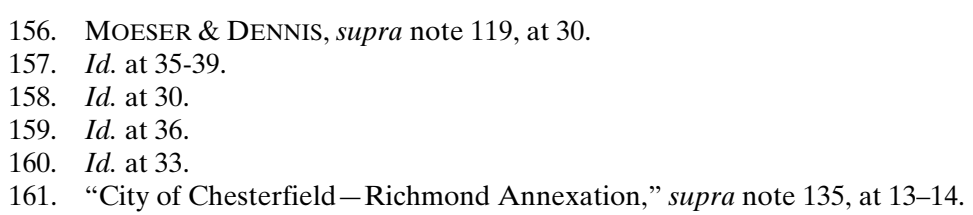


1960 the organized African-American vote was in many cases large enough to hold the balance of power between competing white candidates. ${ }^{162}$

Even at this stage, all parties were well aware that the acquisition of overwhelmingly white suburbs had the potential to slow or reverse the increase in African-American political influence. This reality was clearly reflected in the voting patterns in a 1961 referendum on an ultimately unsuccessful proposal to merge the city of Richmond with nearby Henrico County. While the white voters of Richmond strongly supported the proposal, leaders and voters in the African-American community generally opposed the merger because they feared its impact on the evolving balance of power in the city. ${ }^{163}$

While the victory of a single African-American candidate in the city council elections of 1964 was viewed by some as a harbinger of a new era of racial harmony, the outcome of the 1966 city council elections was more disturbing to many members of Richmond's white elite. In that election, the first to be held after the passage of the Voting Rights Act of 1965 and the elimination of the poll tax by the Supreme Court's decision in Harper v. Virginia State Board of Elections ${ }^{164}$ African-Americans comprised thirty-four percent of the registered voters in Richmond and, by at least one estimate, thirtynine percent of those who actually voted. Moreover, AfricanAmericans claimed three of the nine seats on the council, with one of those seats being filled by Henry Marsh III, a civil rights lawyer who was active in school desegregation litigation. ${ }^{165}$

After this concrete demonstration of the increasing political power of Richmond's black community, the specter of a city council dominated by African-Americans in the near future loomed large in the calculations of some white politicians. Shortly after the election, the Richmond Times Dispatch observed that "if present political trends continue in Richmond, Negro voters will grow steadily stronger, and within a very few years they may be able to elect a majority of Richmond's nine Councilmen." 166 Similarly, the Norfolk Virginia-Pilot asserted that the results of the 1966 election and demographic trends more generally had engendered "a hectic search,

162. Id. at $45-49$.

163. Id. at 38-39.

164. 383 U.S. 663 (1966).

165. MOESER \& DENNIS, supra note 119, at 68.

166. Id. at 69 . 
now under way, for a means to re-establish a white majority in the city's population." 167

Against this background, the issue of annexation loomed large in the city council elections of 1968. Annexation was strongly supported by candidates endorsed by Richmond Forward, an organization that represented the interests of the white establishment in the city. By contrast, the Richmond Crusade for Voters, which was dedicated to enhancing the political power of African-Americans, was willing to support annexation of suburban areas only if the system of at-large elections was abandoned in favor of single member districts. The racial overtones of the dispute were perhaps most clearly reflected in a statement by one of the Richmond Forward candidates, who declared that if the city was unable to obtain jurisdiction over substantial areas in the suburbs, "Richmond will become a permanent black ghetto, a happy hunting ground for ambitious political opportunists." 168

The allies of Richmond Forward retained a majority of the seats on the city council in 1968 and were determined to consummate an annexation agreement with Chesterfield County prior to the 1970 elections. In private negotiations with the Chesterfield County authorities, Richmond Mayor Philip J. Bagley, Jr. and other Richmond officials consistently expressed their desire to add large numbers of suburbanites to the city voting rolls, with Bagley at one point allegedly declaring that "we don't want the city to go to the [black people]. We need 44,000 white bodies"-almost precisely the number ultimately acquired by the city through the annexation agreement. ${ }^{169}$

While there is no reason to believe that Powell knew of this specific statement, he could not have been unaware of the political context in which the debate over the Chesterfield annexation took place. At the same time, it would probably be a mistake to attribute Powell's spirited defense of the legality of both the annexation itself and the existing at large voting system solely or even primarily to a desire to maintain white control of the Richmond city government. Instead, his analysis almost certainly reflected the influence of other factors.

167. Id

168. Id. at 82 .

169. Id. at 93 . 
As his memorandum indicated, Powell believed strongly that expansion was necessary to the health of the city of Richmond, that the at-large system of selecting council members was far superior to one based on single member districts, and that even after annexation the interests of African-American residents would be adequately protected by the existing system. ${ }^{170}$ Seen from this perspective, Powell's effort to convince the Justice Department to approve the annexation without requiring the alteration of the city government might be viewed as less a product of a positive desire to preserve white control of the municipal institutions than of indifference to the impact that the annexation might have on the balance of power in the city.

In addition, the argument in the Chesterfield memorandum also reflected Powell's instinctive distrust of federal intervention into local affairs. Further, he clearly viewed federal intervention in annexation disputes as being particularly inappropriate. Thus, in the memorandum, he declared that "if state and local self-government are to survive in this country, they must be afforded reasonable freedom from federal intervention and control." ${ }^{\prime 11}$ Moreover, while conceding that "the Voting Rights Act of 1965 goes quite far," he insisted that "there was no Congressional intent to frustrate state policy with respect to annexation and to deny to cities the historic rights to expand their boundaries." ${ }^{172}$

In any event, Powell was ultimately unsuccessful in his efforts to preserve the system of at-large elections for the Richmond City Council. The city was forced to accept the conversion to a regime based on single member wards as the price to be paid for retaining the territory annexed from Chesterfield. ${ }^{173}$ Nonetheless, Powell remained firmly committed to the principles that shaped his approach to the annexation controversy and particularly to the view that any ongoing problems of racial discrimination could be adequately addressed without disrupting existing institutional arrangements. This view clearly informed Powell's treatment of many of the constitutional issues that came before him after he became a member of the Supreme Court.

170. "City of Richmond-Chesterfield Annexation," supra note 135, at 15-16.

171. Id. at 19 .

172. Id.

173. City of Richmond v. United States, 422 U.S. 358, 370 (1975). 


\section{POWELL ON THE SUPREME COURT}

\section{A. Nomination and Confirmation}

The sequence of events that led to Powell's nomination to serve on the Supreme Court began with the victory of Richard M. Nixon in the presidential election of $1968 .{ }^{174}$ During his campaign to secure the Republican nomination, Nixon had promised a group of white Southern leaders including Republican Sen. Strom Thurmond of South Carolina that, if elected, he would appoint a white Southerner to the Court as soon as possible. ${ }^{175}$ Despite this representation, Nixon's first nomination was Warren E. Burger of Minnesota, whom Nixon chose to succeed Chief Justice Earl Warren, who had resigned prior to the election. ${ }^{176}$ By contrast, after Abe Fortas was forced off the Court in 1969, Nixon was initially determined to fulfill his pledge and replace Fortas with a Southerner. ${ }^{177}$ Powell's deep Southern roots, long record of public service, and national reputation among the legal establishment made him a strong candidate to succeed Fortas. ${ }^{178}$

Against this background, unbeknownst to Powell himself, he became Nixon's first choice to fill the vacancy that had been created by the Fortas resignation. ${ }^{179}$ However, before Nixon had made a decision on the nomination, Powell sent a letter to the president asking not to be considered for the position. ${ }^{180}$ Nixon then chose Clement F. Haynsworth, a native of South Carolina who was serving as a judge on the United States Court of Appeals for the Fourth Circuit. ${ }^{181}$ After the Haynsworth nomination was rejected by the Senate, Nixon turned to G. Harrold Carswell of Florida, a judge on the United States Court of Appeals for the Fifth Circuit. ${ }^{182}$ When the Senate also refused to confirm Carswell, complaining about what he characterized as unfair prejudice against Southern nominees, ${ }^{183}$ Nixon

174. LAURA Kalman, The LONG REACH OF THE SiXties: LBJ, NiXON AND THE MAKING OF THE CONTEMPORARY SUPREME COURT ch. 7 (2017).

175. Id. at 209 .

176. Id.

177. Id. at 210 .

178. Id. at $210-11$.

179. Id.

180. Id. at 211.

181. Id.

182. Id. at 227-28.

183. Robert B. Semple, Jr., President Bitter, N.Y. TIMES, April 10, 1970 at 14. 
then chose Judge Harry F. Blackmun of Minnesota to succeed Fortas, and Blackmun was confirmed unanimously in $1970 .{ }^{184}$

Nixon was given another opportunity to fulfill his promise to appoint a white Southerner when Hugo L. Black and John Marshall Harlan left the Court in $1971 .^{185}$ After floating a number of other potential candidates who engendered opposition from a variety of different sources, Nixon turned to Powell, whose name was one of those on a list that had been compiled by Chief Justice Burger. ${ }^{186}$ Although Powell first rebuffed overtures from Attorney General John Mitchell, Nixon was ultimately able to persuade Powell to accept the nomination, which was announced publicly on October 20, $1971 .{ }^{187}$

The Powell nomination created considerable consternation among civil rights leaders and some other members of the progressive community. For example, describing Powell as "a white Southerner who had distinguished himself as one of the great forces against civil rights legislation" the head of the Southern Christian Leadership Conference called the nominations of Powell and William $\mathrm{H}$. Rehnquist "insult[s]' to blacks and poor people." 188 Similarly, John V. Lindsay, the progressive Republican mayor of New York City charged that Powell was "insensitive to the most basic problems now dividing the country." 189

However, while they clearly would have preferred a nominee who was more sympathetic to their political perspective, other progressives greeted the Powell nomination with a sense of relief. As one prominent civil libertarian observed, while most progressives were not "elated or even pleased" with the nomination, they were nonetheless "satisfied" with the choice because they believed that Powell would bring "learning and professional competence along with a high sense of purpose to his new office." 190 Similarly, the New York Times asserted that Powell "admirably combines the fundamental requirements of legal and intellectual distinction with Mr. Nixon's

184. KALMAN, supra note 174 , at 245-47.

185. Id. at 292-94.

186. Id.

187. Id

188. John P. MacKenzie, Judiciary Unit Delays Vote on Both Nominees, WASH. Post, Nov. 12, 1971, at A4.

189. Spencer Rich, Hill Reaction is Favorable to Nominees, WASH. Post, Oct. 22, 1971, at A8.

190. Norman Dorsen, A Response to Mr. Powell, N.Y. TIMES, Nov. 16, 1971, at 45. 
insistence on political conservatism."191

Despite the indications that his nomination would be relatively uncontroversial, Powell prepared with his usual meticulousness for his testimony before the Senate Judiciary Committee. ${ }^{192}$ In addition to discussions of potential financial conflicts of interests, most of the questions from the members of the committee focused on wiretapping and other issues related to criminal procedure and the relationship between individual rights and national security. ${ }^{193}$ By contrast, Democratic Sen. Edward M. Kennedy of Massachusetts called on Powell to explain criticisms that Powell had leveled at Dr. Martin Luther King, Jr. during the mid-1960s. ${ }^{194}$

Powell had outlined the nature of his disagreements with King in a lecture that was delivered at Washington and Lee University in April, $1966 .{ }^{195}$ The lecture was, by its terms, a response to King's celebrated "Letter From a Birmingham Jail," in which King declared that "one has a moral responsibility to disobey unjust laws" and contended that the use of civil disobedience was justified as part of the campaign against racial segregation in the South. ${ }^{196}$ Powell agreed that people had a moral right to resist the government in cases where no other means of redress was available. ${ }^{197}$ But at the same time, he also contended that the conditions that might conceivably justify civil disobedience were not present in the United States of the mid-1960s and described the advocacy of civil disobedience in that context as "a heresy which could weaken the foundations of our system of government, and make impossible the existence of the human freedoms it strives to protect." 198

Powell acknowledged that "the Negro has had, until recent years, little reason to respect the law," that "[t]he entire legal process, from

191. The Court Nominations, N.Y. TIMES, Oct. 22, 1971, at 38.

192. See JEFFRIES, supra note 6, at 230.

193. See generally Hearings on Nominations of William H. Rehnquist and Lewis F. Powell, Jr. before the Committee on the Judiciary, United States Senate, 92nd Cong. 201-88 (1971).

194. Id. at 272.

195. Lewis F. Powell, Jr., A Lawyer Looks at Civil Disobedience, 23 WASH. \& LEE L. REV. 205, 205 (1966).

196. Martin Luther King, Jr., Letter from a Birmingham Jail (1963), AFRICAN STUDIES CENTER - UNIVERSITY OF PENNSYLVANIA, http://www.africa.upenn.edu/Articles_Gen/

Letter_Birmingham.html (last visited Mar. 31, 2019).

197. Powell, Jr., supra note 195, at 207-08.

198. Id. at 205. Powell's speech is also discussed in JEFFRIES, supra note 6, at 238-39, and Anders Walker, A Lawyer Looks at Civil Disobedience: Why Lewis F. Powell Divorced Diversity From Affirmative Action, 86 U. COLO. L. REV. 1229 (2015). 
the police and sheriff to the citizens who serve on juries, has too often applied a double standard of justice," and that the situation had been exacerbated by discriminatory state and local laws, denial of voting rights, and a general lack of educational and economic opportunities for African-Americans. ${ }^{199}$ Nonetheless, he insisted that "in America today ... despite some conditions of injustice, wrongs can be and ultimately are redressed in the courts, the legislatures and through other established political institutions." 200 Explicitly analogizing the tactics being employed by the civil rights movements to the efforts of Southern whites to prevent desegregation through "massive resistance," Powell asserted that "if the decision to break the law really turns on individual conscience, it is hard to see in law how Dr. King is any better off than former Governor Ross Barnett of Mississippi, who also believed deeply in his cause and was willing to go to jail." ${ }^{201}$ Similarly, characterizing the decisions of the Supreme Court overturning the criminal convictions of civil rights demonstrators who had been engaging in peaceful civil disobedience as "unwelcome and disturbing precedent[s]," 202 Powell argued that "[i]t would have been wiser public policy, and more consonant with the rule of law, to require resort to the courts rather than self-help where public facilities ... are involved in racial controversy." 203

Powell conceded that, with respect to issues involving race, "civil disobedience tactics [have] accelerated the pace of legislative reform." ${ }^{204}$ But at the same time, he observed that "the ultimate cost of this acceleration may be costly indeed-in terms of racial bitterness and discord, and particularly in the disrespect for law and order engendered and the lawlessness in the streets which the doctrine of disobedience has encouraged." ${ }^{205}$ Noting that the use of the tactics of civil disobedience had already been adopted in protests against a variety of causes that were not directly related to the civil rights movement, Powell suggested that the increasing acceptance of such tactics had contributed to the atmosphere which sparked the violent riots of the mid-1960s and concluded by declaring that "due process

199. Powell, Jr., supra note 195 , at 206-07.

200. Id. at 208 .

201. Id. at 210 (quoting Burke Marshall, The Protest Movement and the Law, 51 VA. L. REV. 785, 800 (1965)).

202. Id. at 214 .

203. Id. at 215 .

204. Id. at 217.

205. Id. 
and democratic procedures, even though painfully slow at times, are a far more dependable and certainly less dangerous means of correcting injustice and solving social problems." 206

In 1968, after race riots swept the nation during the summers of 1966 and 1967, Powell launched another attack on King's tactics and philosophy. In an article published in the New York State Bar Journal, Powell declared that "once lawlessness is tolerated and justified it feeds upon itself and leads either to revolution or violent repressive measures." ${ }^{207}$ Powell acknowledged that King had condemned the riots themselves. ${ }^{208}$ Nonetheless, observing that King had analogized the actions of the United States in the Vietnam War to the tactics of Nazi Germany and had continued to advocate the use of mass demonstrations for the purpose of " dislocating northern cities," Powell insisted that King was "arm-in-arm" with the more radical members of the African-American community who openly advocated the use of violence to oppose what they characterized as the fundamental injustices of American society. ${ }^{209}$

During the mid-1960s, King was a controversial figure, and criticisms of his tactics were not uncommon. ${ }^{210}$ However, in the wake of his assassination in April, 1968-the same month that Powell's last attack was published-King became the iconic symbol of the civil rights movement, and by 1971, any suggestion that a candidate for high office had a generally unfavorable opinion of King had become politically toxic. ${ }^{211}$ Thus, Kennedy's question at the confirmation hearing created something of a problem for Powell.

Powell's response reflected his understanding of the delicacy of the situation. He began by reiterating the contention that the acceptance of a general right to civil disobedience was "quite contrary to the rule of law." ${ }^{212}$ But at the same time, he also took care to

206. Id. at 226-28.

207. Lewis F. Powell, Jr., Civil Disobedience: Prelude to Revolution?, 40 N.Y. ST. B.J. 172, 173 (1968).

208. Id. at 175 .

209. Id.

210. See Jeanne Theoharris, Don't Forget that Martin Luther King Jr. Was Once Denounced as an Extremist, TIME, Jan. 12, 2018, online at http://time.com/5099513/martin-luther-king-daymyths/, (last visited April 23, 2019).

211. See Jonah Goldberg, "Like Lincoln, Martin Luther King, Jr. Belongs to the Ages," NAT'L REV., April 6, 2018, ("[I]t was King's tragically premature death that reminded so many of his historical stature.") online at https://www.nationalreview.com/2018/04/martin-luther-kingjr-like-abraham-lincoln/ (last visited April 23, 2019).

212. Hearings on Nominations of William H. Rehnquist and Lewis F. Powell, Jr., supra note 
emphasize that he was not disputing the right to take actions designed to provide the opportunity to challenge unjust rules in court and declared that King "will be recognized as one of the great leaders of his people." 113 In addition, Powell observed that he agreed with the views that had recently been expressed by Kennedy confidante Archibald Cox, a professor at Harvard Law School and former Solicitor General of the United States, who had also recently published an article that questioned a generalized right to civil disobedience. ${ }^{214}$ Apparently satisfied with this explanation, Kennedy quickly moved on to other matters. ${ }^{215}$

Only Democratic Sen. Birch Bayh of Indiana made any effort to explore Powell's role in dealing with the impact of Brown v. Board of Education on the Richmond school system. ${ }^{216}$ Observing that many in Virginia had argued that the public schools should be closed rather than integrated, and that several Virginia schools had in fact been closed, Powell responded to Bayh by asserting that the principle task was to keep the schools open.

${ }^{217}$ Noting that the state legislature had essentially mandated that integration be postponed indefinitely, Powell conceded that the Richmond schools had not been integrated until ordered to do so by a federal court. ${ }^{218}$ Powell then recounted the dispute over the construction of John Marshall High School, observing that, despite the public statements that he had made at the time, "it was perfectly obvious if we built [the high schools] in the locations recommended by the school board, that they would become integrated in a fairly short period of time ...."219

Bayh then sought to have Powell express his opinion on the practice of busing students for the purpose of achieving racial balance. ${ }^{220}$ Observing that he would undoubtedly be called upon to decide cases involving busing, Powell would say only that "busing has been used in public education for many years" and that the question of whether busing was in the best interest of children and the

\footnotetext{
23 , at 273 .

213. Id.

214. Id.

215. Id. at 274 .

216. Id. at 277.

217. Id. at 278 .

218. Id.

219. Id.

220. Id. at 279.
} 
educational system would have to be decided on a case by case basis. ${ }^{221}$ Similarly, when pressed for his opinion on the constitutional issues related to inequalities in school finance, Powell stated simply that "it is a problem which worried us a great deal when I was on the State board of education primarily because we were more or less powerless to deal with it." 222

Taken as a whole, the committee's questioning of Powell was relatively benign, and nothing in Powell's answers seemed to pose any real threat to his confirmation. However, some members of the civil rights community remained alarmed at the prospect of having Powell serve on the Court. ${ }^{223}$ On November 9, Democratic Rep. John Conyers, Jr. of Michigan, who spoke on behalf of the Congressional Black Caucus, and Henry L. Marsh III, a Richmond attorney who represented the all-black Old Dominion Bar Association, appeared together before the committee and argued that the nomination should be rejected. ${ }^{224}$

Conyers and Marsh castigated Powell for his membership in segregated private clubs, noted that Powell served on the boards of directors of a number of large corporations that had been charged with racial discrimination, and asserted that Hunton and Williams, which had never hired an African-American attorney, in fact had a policy of not considering African-Americans for positions in the firm. ${ }^{225}$ However, their primary focus was on the actions that Powell had taken as a member of the Richmond School Board and the Virginia State Board of Education. ${ }^{226}$ Emphasizing the lack of real integration of the Richmond public schools during Powell's tenure, Conyers and Marsh contended that Powell's opposition to massive resistance had been based on tactical rather than principled grounds, with Conyers declaring that "there were those in Richmond who had good cause to be justly proud of the masterful way in which $\mathrm{Mr}$. Powell had perpetuated the antiquated notions of white supremacy through a clever institutionalization of school segregation" 227 and Marsh asserting that "Mr. Powell had sense enough to recognize the

\footnotetext{
221. Id.

222. Id. at 280.

223. Id. at 349-92.

224. Id.

225. Id. at 385 .

226. Id. at 371 .

227. Id. at 372 .
} 
futility of the massive resistance program and to go for a more sophisticated scheme of evading the Brown decision." 228

However, this assessment was disputed by others who had been involved in the struggle over desegregation of the Virginia schools. For example, Armistead Boothe, a progressive state legislator who had been the public face of the opposition to massive resistance, declared that "the regard for law[] and the farsightedness of a few people like Lewis Powell . . . helped Virginia . . . to survive the Commonwealth's severest test in this century" and asserted that "if the distinguished members of [the Congressional Black Caucus] could remember the 1950's and could get all the available facts ... [t] hey would approve of [Powell's] selection and thank the good Lord they would have him on the Supreme Court." ${ }^{229}$ A number of prominent African-Americans who had worked with Powell expressed much the same view. Thus, Booker T. Bradshaw, the only African-American who had been a member the Richmond School Board in the years immediately following the decision in Brown, wrote that "[d]uring that period I did not observe any evidence of racial prejudice on [Powell's] part. On the contrary, I always found him to be fair, calm, and objective in his approach to the many problems that confronted us." ${ }^{230}$ Similarly, Oliver Hill, the civil rights leader who had spoken at the public meeting dealing with the dispute over the Chandler conversion, described Powell as "a man whose heart is right." 231

Such statements of support did much to blunt the force of the Conyers/Marsh assault on the Powell nomination. In addition, the fact that the Senate had rejected the nominations of Clement Haynsworth and Harold Carswell in 1970 provided Powell's supporters with a tactical advantage. In the wake of the Carswell defeat, Richard Nixon had asserted bitterly that "it is not possible to get confirmation for the judge on the Supreme Court of any man who believes in the strict construction of the Constitution ... if he happens to come from the South." 232 Those who had opposed Haynsworth and Carswell had vehemently denied this charge, claiming instead that the opposition had been focused on the individual characteristics of the nominees. ${ }^{233}$

\footnotetext{
228. Id. at 393 .

229. Id. at 126 .

230. JEFFRIES, Justice Lewis F. Powell, Jr. supra note 6, at 235.

231. $I d$.

232. Nixon Won't Pick 3rd Southerner for High Court, Pittsburgh Post-Gazette (April 10,

233. Id.
} 1970), p. 1. 
The Powell nomination put the latter claim to the test. However one might have characterized his political views, Powell was plainly an extraordinarily competent attorney whose ability and temperament had been lavishly praised by pillars of the legal establishment with a variety of different intellectual and political perspectives. The rejection of such a nominee would in essence have confirmed Nixon's assessment of the Senate's attitude toward conservative appointments from the South.

In addition, and perhaps most importantly, Powell benefited greatly from having his nomination being paired with that of William H. Rehnquist. Rehnquist came to the confirmation process with a long, documented record of hard-edged support for extremely conservative positions. ${ }^{234}$ Whatever flaws progressives might have seen in Powell's record, and whatever concerns they might have had about his nomination, paled in comparison with their alarm at the prospect of Rehnquist joining the Court. ${ }^{235}$ Thus, for example, appearing before the Judiciary Committee on behalf of the NAACP and the Leadership Council on Civil Rights, Clarence Mitchell and Joseph L. Rauh explicitly declined to take any position on the Powell nomination, choosing instead to devote their testimony entirely to an attack on Rehnquist's record. ${ }^{236}$

Against this background, the comments of Conyers and Marsh had no appreciable impact on the confirmation process. Unlike Rehnquist, whose confirmation was opposed by four members of the Senate Judiciary Committee and twenty-six senators on the floor of the Senate, Powell was confirmed almost unanimously. ${ }^{237}$ Moreover, the only senator who cast a negative vote made no reference to Powell's record on civil rights, instead characterizing the nominee as "an elitist [who] has never shown any deep feelings for little people." ${ }^{238}$ Thus, Powell joined the Court on December 7,1971.

\section{B. Race-Related Jurisprudence}

During the fifteen years that he served on the Supreme Court, Powell was called upon to address a wide variety of race-related

234. See, e.g., The Rehnquist Nomination, N.Y. TIMES, December 8, 1971, p. 36.

235. See, e.g., The Senate, the Court and the Nominees-II, WASH. POST, November 28, 1971, p. C6.

236. Hearings on Nominations of William H. Rehnquist and Lewis F. Powell, Jr., supra note 23 , at 290.

237. JEFFRIES, Justice Lewis F. Powell, Jr., supra note 6, at 240

238. Id. 
problems. Powell's analysis of these issues often reflected his belief that African-Americans and other racial minorities had made great progress in the years since Brown had been decided. As already noted, as late as 1966, Powell had acknowledged that "the Negro has had, until recent years, little reason to respect the law," that "[t]he entire legal process from the police and the sheriff, to the citizens who serve on juries has too often applied a double standard of justice." 239 However, Powell also apparently believed that, by the early 1970s, the kind of widespread, systemic racial discrimination that had characterized American society in the pre-Brown era was largely a thing of the past. While he was willing to concede that individual African-Americans and members of other racial minority groups might at times be victims of specific acts of racial discrimination, he was also firmly convinced that, in most cases, racial minorities could expect fair treatment from the institutions of government and from society more generally.

In 1972, this view was clearly reflected in Powell's reaction to a broad-based constitutional challenge to the use of the death penalty in Furman v. Georgia. ${ }^{240}$ Among other things, those who were challenging the constitutionality of capital punishment argued that the manner in which the death penalty was administered discriminated against African-Americans. In responding to this argument, Powell expressed a willingness to consider equal protection challenges to the imposition of the death penalty in specific cases. ${ }^{241}$ But at the same time, asserting that "[t]he segregation of our society in decades past, which contributed substantially to the severity of punishment for interracial crimes, is now no longer prevalent in this country," he contended that "[t]he possibility of racial bias in the trial and sentencing process has diminished in recent years." 242 Similarly, declaring that "the day is past when juries do not represent the minority group elements of the community," Powell insisted that "[t]he assurance of fair trials for all citizens is greater today than at any previous time in our history." 443 Thus, he concluded that "because standards of criminal justice have 'evolved' in a manner favorable to

239. See supra note 199 and accompanying text.

240. 408 U.S. 238 (1972).

241. Id. at 449 (Powell, J., dissenting).

242. Id. at 450 .

243. Id. 
the accused, discriminatory imposition of capital punishment is far less likely today than in the past." 244

Fifteen years later, in an intraoffice memorandum in McCleskey $v$. Kemp ${ }^{245}$ Powell reiterated this view even in the face of a statistical study that concluded that racial issues played a significant role in determining whether the death penalty was imposed in capital cases. In the memorandum, noting that in 1976 the Court had imposed new procedural constraints on the imposition of the death penalty, Powell observed that "the argument that capital punishment is imposed on a racially discriminatory basis could well have been made in cases decided under standardless capital punishment statutes such as those considered in Furman v. Georgia." ${ }^{246}$ But at the same time, he also asserted that "I ... think ... the framework approved by the Court in [1976] . . . is constitutionally sufficient to prevent racial discrimination." ${ }^{247}$ In addition, maintaining that "it is the jury that is a criminal defendant's fundamental 'protection of life and liberty against race or color prejudice,', ${ }^{248}$ Powell's published opinion asserted that "McCleskey's argument that the Constitution condemns the discretion allowed decisionmakers in the Georgia capital sentencing system is antithetical to the fundamental role of discretion in our criminal justice system." ${ }^{249}$ Thus, Powell ultimately found that "the [statistical] study does not demonstrate a constitutionally significant risk of racial bias affecting the Georgia capital sentencing process." ${ }^{250}$

In McCleskey, Powell spoke for the Court in concluding that the Georgia procedure did not run afoul of constitutional norms. Similarly, in cases such as Regents of the University of California $v$. Bakke, ${ }^{251}$ Powell generally held the deciding vote in evaluating the legality of race-conscious affirmative action programs. By contrast, when dealing with issues related to school desegregation remedies

244. Id.

245. 481 U.S. 279 (1987).

246. Memorandum from LFP to Leslie, September 16, 1986, LFP Case File, McCleskey v. Kemp, No. 84-6811, at 2, archived at http://law2.wlu.edu/powellarchives/page.asp?pageid=1350 (last visited Mar. 31, 2019).

247. Id.

248. McCleskey, 481 U.S. at 310 (quoting Strauder v. West Virginia, 100 U.S. 303, 308 (1880)).

249. Id. at 311 .

250. Id. at 314 .

251. 438 U.S. 265 (1978). 
and voting rights, Powell was often unsuccessful in convincing a majority of his colleagues to accept his views.

In the school desegregation cases, Powell often focused on what he viewed as the impropriety of remedial orders that mandated the busing of large numbers of students for the purpose of improving racial balance in the public schools. Such orders had proliferated in the wake of the decision in Swann, where the Court had unanimously rejected Powell's argument and held that, in a situation where an urban school system had previously been segregated by law, an order which mandated the transportation of a substantial number of students was entirely appropriate. ${ }^{252}$ Throughout his tenure as a justice, Powell sought to narrow the scope of this principle.

In this context, Powell's opinions reiterated his commitment to the principle of neighborhood schools and his conviction that the aggressive pursuit of racial balance should often be subordinated to this concept. Thus, in 1973, echoing his brief in Swann, Powell's opinion in Keyes v. School District No. $1^{253}$ asserted that "[n]eighborhood school systems, neutrally administered, reflect the deeply felt desire of citizens for a sense of community in their public education" 254 and observed that "[c]ommunity support, interest, and dedication to public schools may well run higher with a neighborhood attendance pattern: distance may encourage disinterest." 255 Seven years later, his opinion in Estes v. Metropolitan Branches of Dallas $N A A C P^{256}$ was, if anything, even more critical of busing orders, insisting that "it is increasingly evident that use of the busing remedy to achieve racial balance can conflict with the goals of equal educational opportunity and quality schools" and that "[i]n all too many cities, well-intentioned court decrees have had the primary effect of stimulating resegregation."257

Despite such pleas, a majority of the justices who served with Powell on the Burger Court continued to support the use of busing orders in a wide variety of circumstances. ${ }^{258}$ In Milliken v. Bradley, ${ }^{259}$

252. Swann v. Charlotte-Mecklenburg Bd. of Education, 402 U.S. 1 (1971).

253. 413 U.S. 189 (1973).

254. Id. at 246 (Powell, J., concurring in part and dissenting in part).

255. $I d$.

256. 444 U.S. 437 (1980).

257. Id. at 438 (Powell, J., dissenting).

258. See, e.g., Dayton Bd. of Educ. v. Brinkman, 443 U.S. 526 (1979); Columbus Bd. of Educ. v. Penick, 443 U.S. 449 (1979).

259. 418 U.S. 717 (1974). 
four of his colleagues did join Powell in concluding that, in the absence of a showing of an "inter-district violation," remedial orders could not require the transportation of students across district lines. Subject to this limitation, however, at the time that Powell left the Court in 1987, many urban school districts throughout the country remained subject to the requirement that students be transported substantial distances in order to improve the racial balance in public schools. $^{260}$

Powell was no less disturbed by the continuing application of the preclearance requirement of section five of the Voting Rights Act to the Southern states. In 1973, his displeasure was clearly expressed during the consideration of Georgia v. United States. ${ }^{261}$ Georgia did not come to the Court as a constitutional challenge. Instead, since South Carolina v. Katzenbach and its progeny had apparently settled the constitutional issue, the state contended simply that it should prevail on statutory grounds. However, while almost all of Powell's brief published dissent ultimately focused on the statutory issue in Georgia ${ }^{262}$ during the consideration of the case he also challenged the constitutionality of the preclearance requirement itself. ${ }^{263}$

In a memorandum to Justice Potter Stewart, Powell insisted that he would have had no objection to what he described as "a carefully drawn Voting Rights Act which applied uniformly to all fifty states." 264 Indeed, Powell's opinion in Georgia asserted that Congress was under a positive duty to pass legislation that would protect the rights guaranteed by the Fifteenth Amendment. ${ }^{265}$ Nonetheless, Powell was convinced that section five itself was unconstitutional.

Unlike Powell's assessment of the role that racial issues played in the imposition of the death penalty, his criticism of the preclearance requirement does not appear to have rested on the premise that substantial progress in race relations had been made in the postBrown era. Instead, he apparently took the position that the preclearance requirement had been unconstitutional at the time that it was enacted in 1965. In his memorandum to Stewart, Powell

260. See, e.g., Columbus Bd. of Educ. v. Penick, 443 U.S. 449 (1979).

261. 411 U.S. 526 (1973).

262. Id. at 545 (Powell, J., dissenting).

263. See infra note 272 and accompanying text.

264. Memorandum from LFP to Potter Stewart, March 30, 1973, Case File Georgia v. United States, No. 72-75, Harry A. Blackmun Papers, Box 166, Folder 3 (on file, Library of Congress).

265. Georgia, 411 U.S. at 545 (1973) (Powell, J., dissenting). 
complained that the preclearance mandate required states "to go hat in hand [to] obtain the consent of the Attorney General or run the gauntlet of the [federal district court for the District of Columbia] before an act of the state legislature may go into effect." ${ }^{266}$ Moreover, Powell believed that the constitutional problems inherent in section five had been magnified by decisions such as Matthews, and, reiterating the view that he had expressed in his 1971 memorandum on the Chesterfield annexation, complained to Stewart that the application of the Voting Rights Act to annexation decisions "does grievous harm to the orderly development of urban communities."267

Powell was also extremely displeased by the fact that a handful of Southern states had been singled out for unfavorable treatment by section five. Powell conceded that, historically, African-Americans who sought to vote in the South had often faced greater difficulties than their counterparts in other areas of the country. ${ }^{268}$ Thus, an early draft of his opinion in Georgia explicitly acknowledged the fact that "various means, both overt and subtle, have been employed to deny voting rights on racial grounds, and these indefensible practices have been more prevalent in some states and sections of our country than in others." ${ }^{269}$ But the same unpublished draft also observed that, as interpreted by cases such as Allen and Perkins, "section 5 ... appl[ies] to conduct which is common to all of the states" and that "these commonplace changes, often essential to meet neutral and nonracial needs, are not unique to the few states targeted by this discriminatory legislation. They are as national in usage as state and local government itself." ${ }^{270}$ In short, as he observed in the memorandum to Stewart, Powell viewed section five as "discriminatory and indefensible sectional rather than national legislation." ${ }^{271}$

Ultimately, Powell decided against using Georgia as a vehicle to make a detailed argument against the constitutionality of the preclearance requirement. Instead, in his published opinion, he contented himself with the simple observation that "[i]t is indeed a serious intrusion, incompatible with the basic structure of our system, for federal authorities to compel a State to submit its legislation for

266. Mar. 30 Memorandum from LFP to Potter Stewart, supra note 264.

267. Id.

268. Draft opinion, April 2, 1973, LFP Case Files, Georgia v. United States, No. 72-75, at 3 (archived online at http://law2.wlu.edu/powellarchives/page.asp?pageid=1602).

269. Id. at 5 .

270. Id.

271. Mar. 30 Memorandum from LFP to Potter Stewart, supra note 264. 
advance review" and the assertion that this requirement was "rendered the more noxious by its selective application to only a few States." 72 However, seven years later, after Congress had voted in 1975 to once again extend the life of the preclearance requirement, Powell publicly assailed the constitutionality of the application of section five to a Southern municipality in City of Rome v. United States. ${ }^{273}$

City of Rome came to the Court after the municipal government of the city of Rome, Georgia, had unsuccessfully sought preclearance for a number of annexations and changes in the manner that its City Commission and Board of Education were chosen. Following the denial of the preclearance request, the city sought to take advantage of the so-called "bailout" procedure that had been incorporated into the Voting Rights Act. By its terms, the bailout provision provided that a covered "State" could be relieved of the preclearance mandate if the state could demonstrate that no test or other device had been used in the jurisdiction within the past seventeen years "for the purpose or with the effect of denying or abridging the right to vote on account of race or color." 274 The city argued that it was entitled to avail itself of the bailout provision because the city itself had not engaged in any discriminatory practices for the requisite period, notwithstanding the fact that the state of Georgia as a whole had not satisfied the requirements established by the statute. In addition to its statutory arguments, the city government also contended that in this context, Congress could not constitutionally require the city to obtain preclearance before taking the proposed actions.

Speaking for the Court, Thurgood Marshall showed no sympathy for these arguments. In rejecting the constitutional challenge, the majority opinion emphasized the long history of racial discrimination in the South, noting that, in 1965-a full ninety-five years after the ratification of the Fifteenth Amendment-Congress had determined that "racial discrimination in voting was an insidious and pervasive evil which had been perpetuated in certain parts of our country through unremitting and ingenious defiance of the Constitution"'275

272. Georgia v. United States, 411 U.S. 526, 545 (Powell, J., dissenting) (emphasis in original).

273. 446 U.S. $156(1980)$.

274. 42 U.S.C. sec. $1973 b(a)$

275. Georgia v. United , 411 U.S. at 181-82 (emphasis in original) (quoting South Carolina v. Katzenbach, 383 U.S. 301, 309 (1966)). 
and asserting that "in adopting the Voting Rights Act, Congress sought to remedy this century of obstruction by shifting 'the advantage of time and inertia from the perpetrators of the evil to its victims." ${ }^{276}$ Turning specifically to the decision to extend the preclearance requirement in 1975, Marshall noted that "[t]en years later, Congress found that a 7-year extension of the Act was necessary to preserve the 'limited and fragile' achievements of the Act and to promote further amelioration of voting discrimination"277 and concluded that " $[\mathrm{w}]$ hen viewed in this light, Congress' considered determination that at least another 7 years of statutory remedies were necessary to counter the perpetuation of 95 years of pervasive voting discrimination is both unsurprising and unassailable."278

Not surprisingly, Powell viewed the extension of the preclearance requirement quite differently. In the interim between Georgia and City of Rome, Powell had reluctantly concurred in a number of expansive interpretations of the preclearance requirement, reasoning that the results were compelled by the logic of decisions such as Perkins. ${ }^{279}$ However, he was unwilling to countenance the imposition of the preclearance requirement in City of Rome, fuming privately that "this intrusion on the right of cities \& states to determine their own local gov't structure ... is indefensible as applied only to selected states and now has continued long after blacks vote freely throughout the South," 280 and expressing the belief that African-Americans would be able to use their newly-acquired political power to prevent state officials from instituting racially-discriminatory measures. ${ }^{281}$

Moreover, to Powell, the specific facts of City of Rome provided a classic example of what he characterized as the "absurdities" of section five. Among other things, the Attorney General had refused to preclear thirteen proposed annexations. Nine of the thirteen cases involved vacant land, while taken together the remaining annexations would have resulted in a net decline of a total of one percent in the African-American share of the electorate in Rome. Against this

276. Id. at 182 (quoting South Carolina v. Katzenbach, 383 U.S. 301, 328 (1966)).

277. Id.

278. Id.

279. See, e.g., United States v. Bd. of Comm'rs. of Sheffield, 435 U.S. 110, 139-40 (Powell, J., concurring in part and concurring in the judgment).

280. Handwritten Notes on Memorandum from David to LFP, September 17, 1979, LFP Case File, City of Rome v. United States, no. 78-7840 at 1 online at https://scholarlycommons.law .wlu.edu/casefiles/259/, (last visited April 23, 2019).

281. Id. at 6. 
background, Powell argued not only that the Voting Rights Act by its terms allowed the city of Rome to be considered independently for purposes of the bailout provision, but also that it had been unconstitutional for the district court to refuse to allow the city to take advantage of that provision.

Powell began his dissenting opinion in City of Rome by observing that even the majority in South Carolina v. Katzenbach had recognized that the preclearance provision was "an uncommon exercise of congressional power." He argued that section five was "especially troubling because it destroys local control of the means of self-government," 282 which Powell described as "one of the central values of our polity." ${ }^{283}$ Nonetheless, Powell's City of Rome dissent did not explicitly address the broader question of whether Congress had exceeded its constitutional authority by extending the life of the preclearance requirement in 1975 . Instead, he focused specifically on the situation in which local governments found themselves in states such as Georgia.

Powell asserted that "[u]nless the federal structure provides some protection for a community's ordering of its own democratic procedures, the right of each community to determine its own course within the boundaries marked by the Constitution is at risk." 284 Observing that only the need to remedy violations of the Fifteenth Amendment justified the preclearance requirement's intrusion on the right to self-government, Powell contended that any such broad based requirement ran the risk of burdening jurisdictions that had not in fact been guilty of racial discrimination and insisted that only the existence of a bailout procedure made this possibility tolerable. ${ }^{285} \mathrm{He}$ also noted that a regime that made the procedure available only when an entire state could demonstrate that it had been free from racially discriminatory voting practices for seventeen years in essence "makes every city and county in Georgia a hostage to the errors, or even the deliberate intransigence, of a single subdivision." Against this background, Powell concluded that the preclearance requirement could pass constitutional muster only if individual subdivisions were

282. City of Rome, 446 U.S. at 201 (1980) (Powell, J., dissenting).

283. Id.

284. Id. at 201-02.

285. Id. at 202-03. 
entitled to avail themselves of the bailout procedure based solely on local conditions. ${ }^{286}$

In one important respect, Powell's proposed treatment of section five differed radically from the courses of action that he championed in cases such as McCleskey and Keyes. In McCleskey and Keyes, Powell advocated judicial restraint. By contrast, in Georgia and City of Rome, he took the position that the Court should act aggressively to rein in legislative action that threatened what Powell viewed as fundamental precepts of the American political system. Nonetheless, his opinions in all of these cases are connected by a common theme: the view that systemic problems of racism had largely disappeared, and that any remaining issues should be addressed in a manner that did not unduly disrupt existing institutional structures.

However, Powell had only limited success in convincing a majority of his colleagues to embrace this perspective. As already noted, when Powell left the Court in 1987, many jurisdictions remained subject to judicial decrees requiring widespread transportation of students in order to improve the racial balance of public schools. Moreover, the Court's failure to condemn the preclearance requirement had left Powell's native Virginia and a number of other Southern states subject to the strictures of section five of the Voting Rights Act. Thus, Powell could not have been satisfied with the state of the law dealing with these issues at the time that he left the Court. By contrast, he would have been more pleased with the evolution of the doctrines relating to both school desegregation and the Voting Rights Act during the period between the time of his retirement and the present day.

\section{THE TRIUMPH OF THE SOUTHERN MAN}

\section{A. School Desegregation}

The Court's approach to the issues of remedies in school desegregation cases began to change soon after Powell was replaced by Justice Anthony M. Kennedy in 1987. The pivotal moment came in 1991 with the decision in Oklahoma City Board of Education v. Dowell. ${ }^{287}$ Dowell arose from the efforts of the Oklahoma City Board of Education to free itself from the constraints of a desegregation

286. See id. at 203.

287. 498 U.S. 237 (1991). 
injunction that had been issued by a federal district court in 1972 . Under the terms of that injunction, the Board of Education was required to follow the terms of the so-called "Finger Plan," which required the transportation of large numbers of students in order to improve racial balance in the public elementary and secondary schools in Oklahoma City. After following the dictates of the Finger Plan for more than a decade, the Board of Education argued that the school system had achieved unitary status, and that the board should be allowed to implement the terms of a Student Reassignment Plan [hereinafter SRP] under which the Finger Plan would continue to govern the assignment of students in middle school and high school, but elementary school students would be assigned to their neighborhood schools.

Because of residential segregation, adherence to the SRP was certain to dramatically reduce the degree of racial balance in the Oklahoma City schools. Under the terms of the plan, of the sixty-four elementary schools in the system, eleven would be over ninety percent African-American, while the student population of twentytwo schools would be less than ten percent African-American. Nonetheless, the district court concluded that the Board of Education should be allowed to implement the SRP, finding that the Oklahoma City school district had achieved unitary status by faithfully complying with the terms of the 1972 order, that the SRP had not been intentionally designed to increase racial segregation, and that the 1972 injunction should be dissolved. However, the United States Court of Appeals for the Tenth Circuit reversed, holding that the 1972 injunction should remain in place absent "dramatic changes in conditions unforeseen at the time of the decree that ... impose extreme and unexpectedly oppressive hardships on the [Board of Education]" and that Oklahoma City remained under an obligation "not to take any action that would impede the process of disestablishing the dual system and its effects."288

When Dowell came before the Supreme Court, a majority of the justices concluded that the judgment of the court of appeals should be reversed. Speaking for the majority, Chief Justice Rehnquist asserted that "[t] he test espoused by the Court of Appeals would condemn a school district, once governed by a board which intentionally discriminated, to judicial tutelage for the indefinite future" and

288. Id. at 244 (quoting Dayton Bd. Of Educ. v. Brinkman, 443 U.S. 526, 538 (1979)). 
declared that "[n]either the principles governing the entry and dissolution of injunctive decrees, nor the commands of the Equal Protection Clause of the Fourteenth Amendment, require any such Draconian result." 289 While conceding that "a district court need not accept at face value the profession of a school board which has intentionally discriminated that it will cease to do so in the future," Rehnquist also observed that "in deciding whether to modify or dissolve a desegregation decree, a school board's compliance with previous court orders is obviously relevant," noting that "the ... passage of time [between the time that the original decree was entered and 1985] enables the district court to observe the good faith of the school board in complying with the decree." ${ }^{290}$

Rehnquist did not explicitly reinstate the judgment dissolving the 1972 injunction. Instead, he concluded that the district court should be instructed to determine whether the school board had made a "sufficient showing of constitutional compliance" to allow judicial supervision to be terminated and also whether the decision to adopt the SRP had in fact been tainted by racial considerations. ${ }^{291}$ Nonetheless, the majority opinion in Dowell clearly implied that, once a school board had faithfully observed the terms of a desegregation decree for a significant period of time, the board should be freed from the supervision of the federal courts, subject only to the proviso that race should not play a role in determining the policies adopted to govern educational affairs.

Any doubts that might have remained regarding the change in the Court's attitude toward desegregation orders were dispelled the following year by the decision in Freeman v. Pitts. ${ }^{292}$ Freeman involved a dispute over the status of the school system in Dekalb County, Georgia, which had been subject to federal court supervision since 1969 under a consent decree that required the local authorities to replace the segregated system that had formerly been maintained in Dekalb County with an approach designed to create a unitary system. In 1986, in response to a petition to dissolve the consent decree, the district court found that, while the school system had not achieved unitary status in all respects, with respect to student assignments the school system had been "effectively desegregated" for a period of

289. Id. at 249.

290. Id.

291. Id. at 249-250.

292. 503 U.S. 467 (1992). 
time, ${ }^{293}$ and that subsequent changes in racial balance were the result of demographic changes for which the school authorities bore no responsibility. ${ }^{294}$

Against this background, the Freeman Court held that "federal courts have the authority to relinquish supervision and control of school districts in incremental stages, before full compliance has been achieved in every area of school operations $" 295$ and in particular that "the district court may determine that it will not order further remedies in the area of student assignments where racial imbalance is not traceable, in a proximate way, to constitutional violations." 296 Focusing on a theme that had often been emphasized by Justice Powell, the opinion of the Court declared that "[r]eturning schools to the control of local authorities at the earliest practicable date is essential to restore their true accountability in our governmental system" 297 and that "[w]hen the school district and all state entities participating with it in operating the schools make decisions in the absence of judicial supervision, they can be held accountable to the citizenry, to the political process, and to the courts in the ordinary course. ${ }^{298}$

By setting the stage for the end of judicial decrees mandating widespread transportation of children for the purpose of achieving racial balance, Dowell and Freeman in effect embraced the perspective that had been taken by Justice Powell throughout his career on the Court. Within two decades, over half of all the school districts that had been subject to court-ordered desegregation plans had been released from judicial supervision, in many cases paving the way for a return to the kind of neighborhood-based school assignment policies that Powell had so vigorously championed. ${ }^{299}$ Thus, the era of extensive court-ordered school busing had effectively come to an end.

\footnotetext{
293. Id. at 477.

294. Id. at 494.

295. Id. at 490 .

296. Id. at 491.

297. Id. at 490.

298. Id.

299. Sean F. Reardon, Elena Tej Grewal, Demetra Kalogrides \& Erica Greenberg, "Brown" Fades: The End of Court-Ordered School Desegregation and the Resegregation of American Public Schools, 31 J. POL'Y ANALYsIS \& MGMT. 876, 877 (2012).
} 


\section{B. The Death of the Preclearance Requirement}

Powell would have been equally pleased by the ultimate demise of the preclearance requirement of the Voting Rights Act. After he left the Court in 1987, the preclearance requirement was reauthorized for fifteen years in 1992 and for an additional twenty-five years in 2006. The 2006 Reauthorization Act also overruled two Supreme Court decisions that had made it easier for covered jurisdictions to obtain preclearance for changes in election procedures. ${ }^{300}$

Despite these reaffirmations by Congress, the concept of preclearance continued to be the subject of constitutional challenges in the late twentieth century. ${ }^{301}$ However, it was not until 2009 that a majority of the justices first indicated that they had serious doubts about the constitutionality of the 2006 extension. ${ }^{302}$ While the Court did not definitively resolve the constitutional issue at that time, four years later, the five most conservative members of the Court explicitly concluded that the extension was unconstitutional in Shelby County v. Holder. ${ }^{303}$

Speaking for the majority, Chief Justice John Roberts reiterated the standard characterization of the preclearance requirement as " "extraordinary legislation otherwise unfamiliar to our federal system"" 304 that constituted an " extraordinary departure from the traditional course of relations between the States and the Federal Government'." ${ }^{305}$ In addition, he contended that the decision to impose the requirement on some but not all state governments ran afoul of the principle that "all the States enjoy equal sovereignty" 306 and that any departure from this principle required a showing that the disparate treatment of the states was "sufficiently related to the problem that it targets." 307

300. The two decisions were Georgia v. Ashcroft, 539 U.S. 461 (2003), which held that a plan could be precleared even if it reduced minority voters' ability to elect their preferred representatives, as long as it preserved the "opportunity to participate in the political process," and Reno v. Bossier Parrish Sch. Bd., 528 U.S. 320 (2000), which held that section five barred preclearance only for changes that were designed to worsen the existing position of minority voters.

301. See, e.g., Lopez v. Monterey Cty., 525 U.S. 266 (1999).

302. Nw. Austin Mun. Util. Dist. No. One v. Holder, 557 U.S. 193 (2009).

303. 570 U.S. 529 (2013).

304. Id. at 545 (quoting Nw. Austin, 557 U.S. at 211).

305. Id. (quoting Presley v. Etowah Cty. Comm'n, 502 U.S. 491, 500-501 (1992)).

306. $I d$.

307. Id. at 542 (quoting Nw. Austin, 557 U.S. at 203). 
Roberts conceded that in 1965, both the imposition of the preclearance requirement itself and the content of the formula that determined which jurisdictions would be subject to the requirement were justified by the conditions which existed at the time. ${ }^{308}$ At the same time, however, the opinion also cited a variety of evidence that in Roberts's view demonstrated that African-Americans in the Southern states had far greater opportunity to participate in the political process than the statistics from the 1960s and 1970s would suggest. ${ }^{309}$ Thus, insisting that the 2006 extension "imposes current burdens and must be justified by current needs," ${ }^{310}$ Roberts concluded that the original coverage formula could no longer be used to identify the states that would be required to preclear changes in the electoral process, and that, in the absence of the adoption of a formula that more accurately reflected the realities of the early twenty-first century, Congress could not constitutionally subject a small group of states to the preclearance requirement.

The majority opinion in Shelby County thus embraced two of the most important aspects of Justice Powell's worldview. First, the decision was based on the theory that the Southern states were being unfairly singled out for less favorable treatment that was not justified by empirical evidence. In addition, Chief Justice Roberts seems to have shared Powell's conviction that racism was no longer endemic in the United States and that specific instances of racial discrimination could be adequately addressed without unduly disrupting the traditional structure of governmental institutions. The majority opinion acknowledged that, at the time that the Voting Rights Act was passed in 1965, the preclearance requirement had been imposed on the Southern states because Congress had determined that "[c]ase-bycase litigation had proved inadequate to prevent . . . racial discrimination in voting [in those states]." ${ }^{\text {311 }}$ Roberts also conceded that "voting discrimination still exists" 312 and declared that "any racial discrimination in voting is too much." ${ }^{13}$ But at the same time, he insisted that "our Nation has made great strides [in providing AfricanAmericans with access to political power]" 314 and, by invalidating

308. Id. at 545-46.

309. Id. at 547-48.

310. Id. at 542 (quoting Nw. Austin, 557 U.S., at 203).

311. Id. at 545 .

312. Id. at 536 .

313. Id. at 557.

314. Id. at 549. 
section five, implicitly suggested that the standard modes of judicial action could provide a sufficient remedy for any further instances of racial discrimination in the political process. In short, much like Powell before him, Roberts chose to emphasize the progress that had been made in race relations rather than the challenges that remained to be addressed.

\section{CONCLUSION}

Although Lewis Powell would no doubt have been greatly pleased by the tenor of the majority opinion in Shelby County, the opinion did not completely vindicate Powell's view of the state of race relations at the time that he joined the Court. In effectively striking down the preclearance provision of the Voting Rights Act, Chief Justice Roberts focused on the political power available to African-Americans in the early twenty-first century - a power that was on display, for example, in recent statewide elections in Virginia and Alabama, where the African-American vote played a crucial role by providing the margin of victory for Democratic candidates whose opponents received a substantial majority of white votes. ${ }^{315}$ However, the situation in the South was very different in the late 1960s and early 1970s, when Powell often asserted that systemic racial discrimination was already a thing of the past and bitterly described section five as "discriminatory and indefensible sectional rather than national legislation" that "does grievous harm to the orderly development of urban communities [in the South]." ${ }^{316}$

Nonetheless, even if one accepts Roberts' assessment of the current situation with respect to voting rights, the ongoing impact of systemic racial discrimination continues to be apparent in other contexts in which Powell expressed confidence in the ability of existing institutions to treat African-Americans fairly. For example, although white students are now significantly less likely to attend highly segregated schools than in the years before Dowell, the period between 1988 and 2013 witnessed a steady rise in the percentage of students of color who attend public schools that have few white

315. See Exit Poll Results: How Different Groups of Virginians Voted, WASH. PosT, https://www.washingtonpost.com/graphics/2017/local/virginia-politics/governor-exitpolls/?utm_term=.fea4e293a735 (last visited Mar. 31, 2019) (detailing Virginia voting polls); Summer Meza, Who Voted For Doug Jones? White Women Backed Roy Moore, NEWSWEEK, http://www.newsweek.com/doug-jones-roy-moore-alabama-senate-race-special-election-resultsdemographics-746366 (last visited Mar. 31, 2019) (detailing Alabama voting polls).

316. March 30 Memorandum from LFP to Potter Stewart, supra note 264. 
students, ${ }^{317}$ despite research suggesting that children of color are more likely to succeed academically in racially-integrated settings. ${ }^{318}$ Similarly, people of color remain far more likely than whites to be subjected to capital punishment, ${ }^{319}$ and the race of the victim continues to be a significant factor in determining whether a particular defendant is sentenced to die for a crime. ${ }^{320}$

Of course, the fact that such problems continue to exist does not by its terms determine the appropriate role of the judiciary in dealing with these issues. One might, for example, take the view that the underperformance by children of color in urban schools is best addressed through measures designed to improve the quality of those schools rather than the transportation of the students to schools that are outside of their neighborhoods. But no one can plausibly suggest, as Lewis Powell did more than forty years ago, that widespread segregation and racial inequality are no longer problems in the United States, and the analysis of constitutional issues should reflect this reality.

317. Gary Orfield, Jongyeon Ee, Erika Frankenberg, and Genevieve Siegel-Hawley, Brown at 62: School Segregation by Race, Poverty and State, UCLA: THE CIVIL Rights PROJECT, 2 (2016), https://escholarship.org/uc/item/5ds6k0rd (last visited Mar. 31, 2019).

318. Ethnic and Racial Disparities in Education: Psychology's Contributions to Understanding and Reducing Disparities, AMERICAN PSYCHOLOGICAL Association, 58-61 (2012), https://www.scribd.com/document/142923734/Ethnic-and-Racial-Disparities-inEducation (last visited Mar. 31, 2019).

319. Race and the Death Penalty, AMERICAN CIVIL LIBERTIES UNION, https://www.aclu.org/other/race-and-death-penalty (last visited Mar. 31, 2019).

320. Id. 